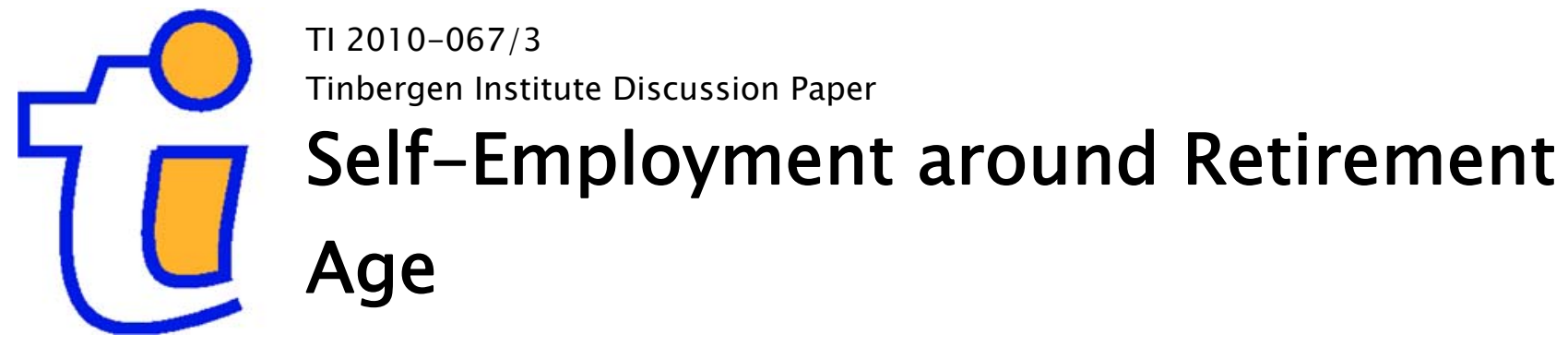

Stefan Hochguertel

VU University Amsterdam, and Tinbergen Institute. 


\section{Tinbergen Institute}

The Tinbergen Institute is the institute for economic research of the Erasmus Universiteit Rotterdam, Universiteit van Amsterdam, and Vrije Universiteit Amsterdam.

Tinbergen Institute Amsterdam

Roetersstraat 31

1018 WB Amsterdam

The Netherlands

Tel.: +31(0)205513500

Fax: $+31(0) 205513555$

Tinbergen Institute Rotterdam

Burg. Oudlaan 50

3062 PA Rotterdam

The Netherlands

Tel.: + $31(0) 104088900$

Fax: $+31(0) 104089031$

Most TI discussion papers can be downloaded at http://www.tinbergen.nl. 


\title{
Self-employment around Retirement Age
}

\author{
Stefan Hochguertel \\ VU University Amsterdam, Tinbergen Institute and Netspar
}

Second draft. July 2010

\begin{abstract}
This paper uses panel data from the pan-European SHARE survey to study labor market behavior of older male self-employed visa-vis wage employed workers.

We find the self-employed to work longer hours, to be more flexible in their hours allocation, and to retire later in all countries. We relate these differences in observed behavior to individual characteristics, economic resources, and to documented cross-national variation in labor market and social security institutions. Differential incentives matter for the retirement behavior of the self-employed. We also provide evidence of the self-employed not wanting to retire as early as possible, and contrast these expectation data with realized retirement transitions. The overall picture that emerges is that older self-employed have a very strong labor market attachment and they use their degrees of freedom to work more and retire later accordingly.
\end{abstract}

JEL codes: J14, J22, J26, L26

Key words: self-employment, labor supply, retirement, pensions, Europe, institutions

Correspondence to: Stefan Hochguertel, Department of Economics, VU University, De Boelelaan 1105, 1081 HV Amsterdam, The Netherlands; e-mail: shochguertel@ feweb.vu •nl

This is a substantially changed version of an earlier draft. The study received partial financial support from Netspar. Many thanks for insightful comments to Simon Parker as well as to discussions by Radim Bohacek and other participants of the first SHARE meeting at Lund (Sweden) of a first draft of this paper. See Section C.3, page 44, for data acknowledgment. 


\section{Introduction}

Among the occupational, life-cycle career choices that individuals can make, the decision whether or not to become self-employed so as to engage in entrepreneurial activity is particularly important and has received corresponding academic interest. Much less is known about labor market choices and retirement behavior of the self-employed when the end of the working life cycle draws nearer.

Studying the older self-employeds' behavior is interesting and important since (i) they need to provide to a much larger extent for their own retirement, and (ii) they constitute a very heterogeneous group comprising not only successful entrepreneurs but also marginalized workers that have difficulties finding regular employment, or do not have access to comparable pension provisions as employees. The self-employed hence form a potential target group for government policy. (iii) Self-employment offers much larger flexibility in terms of labor supply and retirement choices. Self-employeds' behavior can thus be meaningfully studied in comparison to wage employees whose choice set is arguably restricted.

Selection into self-employment and entrepreneurial start-up has been investigated in a number of contributions (for instance, Evans and Jovanovich, 1989; Blanchflower and Oswald, 1998), as has survival in self-employment (Holtz-Eakin et al., 1994; Taylor, 1999). Studies on self-employment exit into retirement are scarce (Parker and Rougier, 2007). Some attention has been paid to self-employment being a bridge job mode on the way to complete retirement (Quinn, 1980; Fuchs, 1982).

Conversely, typical retirement studies either explicitly exclude the self-employed, or are silent about inclusion (Berkovec and Stern, 1991, Blau, 1994, Diamond and Hausman, 1984, Gustman and Steinmeier, 1984, Meghir and Whitehouse, 1997, Ruhm, 1990, Stock and Wise, 1990), or do not pay particular attention to them (Gustman and Steinmeier, 2001; Maestas, 2010; Peracchi and Welch, 1994). Labor supply studies almost exclusively focus on wage employees (see the references in Blundell and MaCurdy, 1999).

This paper investigates hours worked, retirement options and retirement behavior of the self-employed using comparable micro data from eleven OECD countries. The data is drawn from the first two waves of the SHARE project, an international data collection effort on health and retirement issues in Europe. The sampled population are residents aged 50 and above, making the survey largely comparable to its well-known older US sibling, the Health and Retirement Study (HRS).

The present paper not only contributes to narrowing the gap in knowledge about work and retirement behavior of older self-employed in comparison to wage employees, but also contains other additions to the existing relevant literature. First, it uses very suitable 
and unique data that are tailored to studying labor market behavior at older working ages, as well as retirement behavior of individuals, and provide a relatively large cross sectional base. Secondly, the data used is very informative not only on labor market status but also on a number of relevant characteristics such as industry (and occupation), accumulated wealth, income, and health, and answers to a battery of self-evaluation questions. Our goodness of fit statistics show that we can explain a substantial degree of the observed variance through our observed variables.

The data contains information on wishes and expectations for future retirement, and the panel structure of the data enables us to analyze individual transitions. Lastly, since the data is based on samples from a number of different European countries, part of the variation in the data is arguably due to differences in pension rules and retirement regimes that treat the self-employed differently from wage employees, and possibly differently so in different countries. We can then focus on studying the residual variation due to individual characteristics.

Our main findings are that the self-employed aged 50 and over are more flexible in their hours allocation and work substantially more hours per week. They are much less keen on retiring as early as possible, and actually do retire later.

One potential reason for later retirement is lower access to pension benefits. We document differences across countries with a large variation in institutional rules. In addition, we exploit information at the individual level on availability of future pension benefits, and can thus control for differences between employees and self-employed pension rights as a reason to retire.

Another possible way to explain differences in work and retirement behavior are systematic differences in health status. There is reason to believe that career selfemployment is driven by selective characteristics, and innate health and morbidity may impact on the occupational choice early in life. Those who are healthier might be both more willing and able to select into employment modes that require long hours and many years. We can, using our data, control for a range of different health measurements and therefore control for long-run health dynamics at the individual level.

A final channel to explain differences is wealth: the self-employed may have accumulated perhaps lower levels of savings that can be used to finance consumption in older ages, everything else equal. Information on individual net worth is available. The selfemployed hold on average more wealth. But even after instrumentation to account for potential endogeneity, differences in wealth are not main drivers of differences in behavior.

All this suggests that much more than institutional restrictions and financial incentives to retire play a role. The remaining variation may plausibly be explained by deriving 
particular, intangible benefits from working on own account. Hamilton (2000) has stressed such compensating differentials to explain the shortfall of earnings in self-employment compared to wage employment.

Main patterns of hours, labor force participation and retirement across employment modes are similar after accounting for country fixed effects. Indeed, a brief check with data from the HRS (wave 2004) corroborates the main patterns for the United States. This may indicate that just looking at European data is not actually restrictive.

Section 2 introduces data and presents descriptive statistics, Section 3 contains regression results. Short conclusions are offered in Section 4.

\section{Data and Descriptives}

\subsection{Sample}

The micro data we analyze are from the pan-European SHARE project. ${ }^{1}$ This is a panel data survey, currently with 2 waves in public release. The data covers 15 countries from various European regions. ${ }^{2}$ We focus on the 11 countries that were part of the survey in both waves. The first wave sample was drawn in 2004 (and for Belgium and subsamples of France and Greece in 2005), the second wave in 2006/2007. 3

The sample is representative of the population aged 50 and above in any one country. Purpose of the survey is to help obtain a detailed picture of health and retirement related issues for the population covered. The data design is inspired by and most closely resembles the familiar US Health and Retirement Study.

Relevant domains covered in the SHARE survey are employment and work history, income, consumption, wealth, and health. Amounts of income and wealth concepts used in this paper have been converted to Euros and corrected for differences in purchasing power across countries. ${ }^{4}$

For the study of labor supply and retirement related issues of the self-employed, the unique data source has a number of strengths deserving emphasis. One aspect is sample size. In a typical cross sectional data set with a handful of thousands of observations, only a small subset of people will be in the relevant age range, and an even smaller one will be self-employed. The literature on self-employment indicates that there is substan-

\footnotetext{
${ }^{1}$ To be specific, we data release R2.3.0 of November 13, 2009.

2 Austria, Belgium, Czech Republic, Denmark, France, Germany, Greece, Ireland, Italy, the Netherlands, Poland, Spain, Sweden, and Switzerland. In addition, a sample from Israel is also included in the data base.

${ }^{3}$ Countries Czech Republic, Poland, and Ireland, were added as per the second wave. Israel was only included in the first wave.

${ }^{4}$ Germany in 2004 is the base country and year. Using deflated Euro amounts instead does not lead to differences, however. We use country dummies in all regressions.
} 
tial heterogeneity in terms of who becomes and who stays self-employed. It is therefore instrumental to characterize workers in many observables ways. Importantly, we observe age, demographics and other household background characteristics, wealth, income, industry and occupation. The fact that we have data from many countries yields in addition institutional variation in retirement and pension systems that is worth emphasizing.

The full SHARE sample of the 11 countries considered consists of 28,517 respondents in 19,548 households. We shall in this paper focus on heads of households and thus not consider multiple individuals from the same household. We define as head of household the oldest male in the household among the following persons: the coverscreen respondent, or his or her spouse or partner. ${ }^{5}$

We focus on males for two main reaons. Labor force participation rates are comparatively higher for males in the age group of just over 50 years. Self-employment is in most countries a male-dominated mode of activity, and particularly so at older ages. Removing females and non-heads of households leaves us with 12,524 observations. Of these, 10,525 are in the age range 50-75. The age restriction is chosen to allow for an analysis of labor market behavior beyond standard retirement age. At all ages we find people working and being retired. ${ }^{6}$

Labor market status is self-reported. Conditional on labor force participation, selfemployment is elicited by way of self report. The definition includes those working for a family business. We also include among the self-employed those that report one selfemployed activity out of possibly two jobs.

Table 1 shows variable means of labor market variables and household characteristics, split into two subsamples according to retiree status. A little more than half of the sample is retired at the time of interview, around $40 \%$ works for money.

The non-retired are on average nearly 56 years old, 84\% work (possibly next to being unemployed, disabled, or out of the labor force), and more than a quarter of those working is self-employed. $38 \%$ of household heads in this subsample hold what might be called a 'high school' degree, $26 \%$ have a 'college degree'. ${ }^{7}$ Three quarters are married (or partnered). Chronic health conditions and sickness symptoms are widespread.

Comparing the non-retirees with the retirees we see differences that are in line with expectations. Retirees are a good 10 years older. $6.5 \%$ of retirees work. Educational dif-

\footnotetext{
${ }^{5}$ We have alternatively considered to condition on the household member's role as financial respondent, which is the person who is deemed financially most knowledgeable in the household. Doing so reduces the number of observations without substantially altering results.

${ }^{6}$ There are very few people working beyond age 75 , and most of our analyses pertains to those working.

${ }^{7}$ Education systems differ widely between countries and have changed substantially over the decades. SHARE researchers expended large efforts at measuring education in a comparable way. All education dummy variables used are based on the United Nations ISCED-97 classification.
} 
Table 1: Sample Characteristics (Sample Means)

\begin{tabular}{lrr}
\hline \hline Variable & non-ret. & retirees \\
\hline age & 55.75 & 66.39 \\
(previously) self-emp. & & 0.148 \\
self-employed & 0.263 & \\
works & 0.839 & 0.065 \\
unemployed & 0.104 & - \\
disabled & 0.079 & - \\
other labor force & 0.002 & - \\
out of labor force & 0.008 & - \\
edu.: none & 0.038 & 0.075 \\
edu.: primary & 0.136 & 0.262 \\
edu.: (lower) secondary & 0.130 & 0.129 \\
edu.: (upper) secondary & 0.381 & 0.345 \\
edu.: post-sec., non-tertiary & 0.022 & 0.012 \\
edu.: 1st tertiary & 0.261 & 0.164 \\
edu.: 2nd tertiary & 0.023 & 0.007 \\
edu.: other & 0.007 & 0.005 \\
foreign-born & 0.116 & 0.108 \\
household size & 2.560 & 2.135 \\
marital st.: couple & 0.762 & 0.801 \\
marital st.: nvr. married & 0.096 & 0.071 \\
marital st.: widowed & 0.029 & 0.072 \\
marital st.: div./sep. & 0.113 & 0.056 \\
other hh income (100k EUR) & 0.258 & 0.403 \\
private net worth (m EUR) & 0.360 & 0.285 \\
long-term sickness & 0.402 & 0.532 \\
number of chronic conditions & 1.011 & 1.581 \\
number of symptoms & 0.978 & 1.279 \\
body mass index & 26.68 & 27.06 \\
\hline \hline
\end{tabular}

Notes: SHARE sample of male household heads, age 5075. Subsample non-retired: 5,072 obs.; self-employed conditional on working; 'works' includes e.g., disabled and unemployed that work nevertheless. Retiree sample: 5,453 obs. Variables in both subsamples may contain different numbers of missing values. Education level according to United $\mathrm{Na}-$ tions ISCED coding. Weighted statistics. 
ferences will partly be due to generational differences, whereas health will be strongly influenced by age, and differences in family composition and marital status will result from both age and cohort effects. Retirees hold less wealth, but command over higher 'other household income' - this excludes earnings of the head of household; use of this income concept explains the positive difference between samples.

\subsection{Labor Force Participation and Self-employment}

Strong inter-country differences can be found in Table 2 showing both labor force participation and self-employment rates from our SHARE sample.

Table 2: Labor Force Participation \& Self-employment Rates

\begin{tabular}{lrrrrrrrr}
\hline \multicolumn{1}{c}{ Age } & \multicolumn{3}{c}{ 50-RA } & \multicolumn{3}{c}{$55-64$} & \multicolumn{2}{c}{$\geq$ RA } \\
country & LFP & SE & SEN & LFP & SE & SEN & LFP & SE \\
\hline Austria & 52.4 & 20.4 & 16.9 & 37.6 & 19.8 & 17.8 & 6.6 & 18.8 \\
Belgium & 61.9 & 20.1 & 17.1 & 48.7 & 25.2 & 20.5 & 5.4 & 54.8 \\
Switzerland & 85.8 & 30.9 & 23.2 & 81.0 & 34.4 & 27.1 & 30.9 & 59.7 \\
Germany & 73.6 & 20.4 & 17.2 & 60.7 & 24.4 & 21.2 & 8.6 & 44.6 \\
Denmark & 79.2 & 20.9 & 13.6 & 71.9 & 21.5 & 15.5 & 18.5 & 18.8 \\
Spain & 70.6 & 30.8 & 30.0 & 61.8 & 30.3 & 29.7 & 4.7 & 37.1 \\
France & 82.3 & 18.7 & 16.5 & 51.4 & 21.3 & 17.9 & 9.3 & 33.8 \\
Greece & 76.4 & 46.0 & 43.7 & 65.0 & 47.2 & 45.7 & 13.9 & 64.0 \\
Italy & 58.5 & 44.8 & 43.0 & 47.2 & 50.7 & 48.6 & 8.4 & 68.2 \\
Netherlands & 70.4 & 15.3 & 12.6 & 58.6 & 16.0 & 13.3 & 5.1 & 47.6 \\
Sweden & 82.6 & 23.1 & 17.7 & 75.8 & 23.2 & 17.8 & 14.7 & 48.7 \\
\hline \hline
\end{tabular}

Notes: SHARE sample of male heads of household, age 50-75. LFP: labor force participation rate. SE: total self-employment rate (includes workers with another job as wage employee), SEN: net self-employment rate (excludes workers with another job as employee). RA: standard (social security) retirement age.

We split the sample according to broad age groups. The first considers individuals below standard retirement age. ${ }^{8}$ Labor force participation rates range from a low $52.4 \%$ in Austria to a high $85.8 \%$ in Switzerland.

Labor force participation seems uncorrelated in the cross section with total self-employment rates (including self-employment from second jobs) that range from a low $15.3 \%$ in the Netherlands to a high $46 \%$ in Greece. Column 3 of the Table only counts those as selfemployed that do not also have a second job as wage employed. Only few people work both in wage employment and self-employment, although there are country-specific differences.

\footnotetext{
${ }^{8}$ Standard retirement age for public pensions in 2003 for males was 65 in almost all cases, France being the exception with 60 years. There is slightly more variation for females, see Duval (2003).
} 
The main impression gained from these numbers confirms the picture from OECD statistics ${ }^{9}$ for all age groups that show pronounced and persistent differences in selfemployment rates across countries. Mediterranean countries have in general very high self-employment rates, Northern countries very low ones, compared to Western or Central Europe. In addition, most countries show a decline in total self-employment over much of the 1990's and early 2000's. Levels and downward trend differ heavily by industry composition, however, as self-employment rates are lower across the board in non-agriculture, with a mitigated downward trend.

The next set of columns of Table 2 shows values for the pre-retirement age group of 5564 years. The last couple of columns focus on the population above standard retirement age. Among those few workers that work after standard retirement age, a very large share tends to be self-employed. Differences between countries become even more pronounced, in terms of both labor force participation and self-employment.

Figure 1 plots labor force participation rates and self-employment rates as a function of age. ${ }^{10}$ Age is on the horizontal axis, with the origin at standard retirement age. Many countries exhibit increasing self-employment rates with age, mirroring the decreasing labor force participation rate. These figures suggest that the self-employed have a lower conditional exit rate than wage earners. ${ }^{11}$

\section{Figure 1 about here}

For comparison, Table 3 reports published data, partly based on OECD statistics. The first three columns show labor force participation rates of older men (55-64) in 2003 and 2000 and effective retirement ages in 2000.

The 2003 labor force participation rates from Table 3 can be directly compared with the corresponding figures in Table 2, column 4 . Whereas there are many countries where labor force participation rates from both sources are very close, it appears that SHARE (partly drastically) oversamples the active population in Belgium, Greece and Germany, and undersamples it in Austria compared to OECD data.

Between-country patterns of labor force participation have been documented in Gru-

\footnotetext{
${ }^{9}$ OECD data are readily available from www. sourceoecd.org. Parker and Robson (2004) provide time-series analysis on aggregate OECD statistics.

${ }^{10}$ These are cross-sectional nonparametric regressions. Since the data is very sparse at higher ages, we use a data-adaptive smoother, Koehler et al. (1997).

${ }^{11}$ See Haider and Loughran (2010) for a similar picture using US data. The alternative of a larger inflow into self-employment at older ages than into wage employment can be ruled out by the evidence provided in Table 7 that we discuss below. The cause of a lower exit rate may have to do with differential characteristics leading to different selection effects out of the labor force for self-employed versus wage employed (unobserved heterogeneity) instead of differences in employment hazards. Our regression analyses below suggest that selection through unobservables may still play some role.
} 
Table 3: Labor Force Participation and Retirement Incentives

\begin{tabular}{|c|c|c|c|c|c|c|c|c|}
\hline \multirow[b]{3}{*}{ country } & \multirow{3}{*}{$\begin{array}{c}2003 \\
\text { LFP } \\
M, 55-64^{\star}\end{array}$} & \multicolumn{6}{|c|}{2000} & \multirow{3}{*}{$\mathrm{TFR}^{\sharp}$} \\
\hline & & LFP & ERA & $\mathrm{RR}$ & IT & $\mathrm{RR}$ & IT & \\
\hline & & $\mathrm{M}, 55-64^{\star}$ & $\mathrm{M}^{\dagger}$ & \multicolumn{2}{|c|}{ at age $60^{\ddagger}$} & \multicolumn{2}{|c|}{ at age $65^{\ddagger}$} & \\
\hline Austria & 42.3 & 44.5 & 58.8 & 0 & 9 & 72 & 68 & n.a. \\
\hline Belgium & 39.4 & 36.3 & 57.8 & 49 & 47 & 52 & 55 & 9.0 \\
\hline Switzerland & 79.5 & 79.3 & 62.5 & 22 & 22 & 63 & 19 & n.a. \\
\hline Germany & 52.0 & 52.4 & 60.8 & 17 & 18 & 48 & 0 & 3.5 \\
\hline Denmark & 70.8 & 64.5 & 61.1 & n.a. & n.a. & n.a. & n.a. & n.a. \\
\hline Spain & 62.9 & 60.5 & 61.0 & 59 & 33 & 82 & 92 & 2.5 \\
\hline France & ${ }^{a} 47.0$ & 41.7 & 58.7 & 61 & 51 & 71 & 71 & 7.4 \\
\hline Greece & 60.7 & 57.3 & 62.5 & n.a. & n.a. & n.a. & n.a. & n.a. \\
\hline Italy & 44.4 & 42.7 & 59.5 & 70 & 21 & 95 & 88 & 9.3 \\
\hline Netherlands & 58.7 & 50.8 & 59.2 & ${ }^{b} 80$ & $b_{94}$ & 61 & 0 & 9.0 \\
\hline Sweden & 75.5 & 72.8 & 62.1 & 43 & 35 & 78 & 44 & 2.2 \\
\hline
\end{tabular}

Sources: ${ }^{\star}$ OECD (2004), Table C, ${ }^{a} 2002 ;{ }^{\dagger}$ Duval (2003), Fig. 1, ${ }^{\ddagger}$ Figs. 2 and 4, approx. values; ${ }^{\sharp}$ Gruber and Wise (2004), approx. values. Notes: ${ }^{b}$ based on 'VUT' ER plans; LFP-Labor force participation rate, ERA-effective retirement age, RR-replacement rate, IT-implicit tax in old age pension systems on continued work, TFR-tax force to retire (cumulated IT from early retirement age to age 69).

ber and Wise (1998) and Blöndal and Scarpetta (1999), using somewhat older data. Labor force participation decreased. Our comparison with the year 2000 in column 2 shows a noticeable increase in labor force participation. Austria appears to be the only country where participation of older males has noticeably declined between 2000 and 2003.

Columns four through seven of Table 3 show retirement incentives in public pension systems, calculated by Duval (2003). Two scenarios are compared: retirement at age 60 and at age 65. The Table shows pension/earnings replacement rates at these ages and the implicit tax if people choose to work longer (in 2000). Again, there is substantial variation across countries. Many countries have a large disincentive to work beyond standard retirement age of $65 .{ }^{12}$ This is particularly true for countries such as Austria, France, Italy or Spain, where the implicit tax lies in the range of $68 \%-92 \%$. The same countries also have rather high replacement rates of $71 \%-95 \%$. Countries where such disincentives are absent, like the Netherlands or Germany, have substantially lower replacement rates of $61 \%$ and $44 \%$, respectively. ${ }^{13}$ Early retirement is also often possible, at least for workers. Again,

\footnotetext{
${ }^{12}$ 'Implicit tax' refers to the ratio of social security wealth accrual from working one more year and net earnings. In most countries, actuarially unfair systems have social security wealth decline with age, from which a strong incentive to retire early derives.

${ }^{13}$ These replacement rates refer to before-tax incomes; after-tax replacement rates tend to be substantially higher, and can exceed $100 \%$, especially in countries such as Italy.
} 
substantial disincentive effects of working beyond the earliest possible retirement age are prevalent in many countries. These early retirement incentives contribute to the large gap between standard and actual retirement ages. ${ }^{14}$ Gruber and Wise $(1998,2004)$ prefer to sum the implicit tax over a number of ages around retirement to assess the impact of the 'tax force to retire'; their numbers are replicated in column eight of our Table, indicating the strongest incentives for Italy, the Netherlands, and Belgium.

\subsection{Self-employed and Wage Employed Workers}

Returning to SHARE data, Table 4 splits the working sample into self-employed and wage employed and tabulates industry affiliation and occupation (see Section C.1 for details on definitions). Stark differences exist between both groups.

The self-employed are particularly strongly represented in agriculture, wholesale and retail, and in various 'other' categories. We use a separate category for 'missing industry' (good for almost $10 \%$ of the sample) to capture the fact that not all observations could be consistently coded into industry affiliation. This appears to be more of an issue for the selfemployed. In terms of occupation, the self-employed are particularly prone to be classified as having an administrative or managerial function, but also to be 'skilled farm workers'. Elementary occupations including clerks and operators are quite underrepresented among the self-employed. Again, a category 'missing' shows that many self-employed are not easy to classify.

The data does not have much information on firm characteristics. One variable of interest is firm size, the distribution of which is shown in Table 5.

Almost half of the self-employed work on their own, another two fifths employ at most five employees. We shall return to comparing the characteristics of the self-employed and wage workers in Section 3.1.

\subsection{Labor Supply and Labor Market Dynamics}

Stark differences exist between wage earners and self-employed workers in terms of actual hours worked. Employees are often constrained in their choice of hours by institutional (contractual) parameters. ${ }^{15}$ The self-employed are much more flexible in adjusting their hours according to their wishes and needs. This is borne out in the density estimates displayed in Figure 2, where we see for employees a pronounced spike around standard

\footnotetext{
${ }^{14}$ The Netherlands sticks out in this comparison, since the underlying calculations are based on an early retirement plan (VUT) that has been phased out and replaced with an actuarially fair version (PP) whose disincentive effects are far less pronounced, see Euwals et al. (2005).

${ }^{15}$ See Dickens and Lundberg (1993) for an empirical analysis, showing that a substantial fraction of their sample would like to work more. Also see Martinez-Granado (2005) and references therein.
} 
Table 4: Industry and Occupation

\begin{tabular}{lrrr}
\hline \hline Industry & empl & self & all \\
\hline agriculture \& mining & 1.41 & 4.75 & 2.31 \\
manuf., low tech & 16.50 & 10.02 & 14.75 \\
manuf., high tech & 7.98 & 4.10 & 6.93 \\
supplies \& construction & 13.09 & 12.20 & 12.85 \\
wholesale, retail & 7.53 & 17.79 & 10.31 \\
transp., comm., finance & 11.17 & 5.41 & 9.61 \\
other sophisticated & 17.32 & 8.64 & 14.97 \\
educ., health, soc. work & 12.31 & 6.94 & 10.86 \\
other services & 5.20 & 8.82 & 6.18 \\
other & 0.94 & 1.49 & 1.09 \\
missing & 6.56 & 19.83 & 10.15 \\
\hline Occupation & & & \\
\hline admin./managerial & 11.65 & 21.66 & 14.36 \\
professionals & 15.98 & 17.16 & 16.30 \\
technicians & 17.00 & 14.12 & 16.22 \\
clerks & 6.50 & 0.77 & 4.95 \\
service/sales workers & 5.25 & 4.29 & 4.99 \\
skilled farm worker & 1.82 & 12.63 & 4.74 \\
craftsmen & 18.12 & 15.64 & 17.45 \\
operators & 11.25 & 3.68 & 9.20 \\
elementary occupations & 7.97 & 2.82 & 6.57 \\
other, inc. armed forces & 2.01 & 0.65 & 1.64 \\
missing & 2.45 & 6.59 & 3.57 \\
\hline Tenure in previous job & 27.35 & 34.18 & \\
\hline \hline
\end{tabular}

Notes: SHARE sample of working male heads of households. Industry and occupation: classification according to current worker status. Tenure in previous job (years): worker status in previous job, retiree sample. Weighted statistics. Industry coding following NACE classification. Occupation coding according to ISCO.

Table 5: Firm Size Distribution Self-employed

\begin{tabular}{lrlr}
\hline \hline \# employees & \%-age & \# employees & \%-age \\
\hline none & 48.31 & & \\
$1-5$ & 39.41 & $25-199$ & 1.93 \\
$6-15$ & 7.51 & $200-499$ & 0.80 \\
$16-24$ & 1.43 & $500+$ & 0.61 \\
\hline \hline
\end{tabular}

Notes: SHARE sample of working male heads of households. Weighted statistics.

hours (36-40) in each country. ${ }^{16}$ The hours distribution for the self-employed is mostly

\footnotetext{
${ }^{16}$ These estimates are substantially smoothed in the sense that the raw data reveal lots more spikes at certain, even numbers of hours, say 15, 30, 35, 45, etc. Hours worked here is the sum of hours worked in the main job
} 
bell-shaped and much less peaked, with mean, median, and variance being much larger than those for employees in each of the countries. Some countries display substantial bimodality for the self-employed, with a smaller mode at lower hours.

\section{Figure 2 about here}

The self-employed appear to show higher labor market attachment also in terms of job tenure. Table 4 reports average tenure on the respondent's previous job for the retiree sample. The (previously) self-employed have on average been 7 years longer on their job than employees. ${ }^{17}$ The high average tenure suggest that first entry into self-employment is made at fairly young ages.

The self-employed are not only far less constrained in their hours choice, they also face substantially more flexibility in terms of working after retirement. One question asks retirees whether or not their last job before retirement offered them opportunities to work full- or part-time after the official retirement age. This is answered affirmatively by $70 \%$ of all previously self-employed and by one third of previously wage employed men in the sample. Notwithstanding inter-country differences in levels, the self-employed indicate higher flexibility in every country in the sample.

This flexibility is actually used. The survey contains valuable information on the year a pension was drawn for the first time for a wide array of different pension incomes, and we choose the minimum of all indicated years. From here, we can tabulate average ages in Table 6. The self-employed are older when they draw their first pension, in all countries. The differences with employees can amount to several years in some countries, for instance, Greece, Denmark, Spain, or the Netherlands. In most of the countries, the difference is statistically different from zero. ${ }^{18}$

Assessing labor market dynamics is possible by using information from the second wave of the survey. Out of the 10,525 observations in wave 1, 7,026 are also present in wave $2 .{ }^{19}$

\footnotetext{
and possibly a second job. For a total of five observations, reported hours exceeding 140 were set to missing.

${ }^{17}$ The questionnaire does not probe whether the respondents view an intermittent business termination and subsequenlty restarting a new venture as a change of job, or whether they associate the tenure question as pertaining to a self-employment career. Conversely, former employees may define a change in jobs to include a change in tasks.

${ }^{18}$ This difference will however explain only a small part of the above-noted difference in tenure between both groups.

${ }^{19}$ There is no strong a priori evidence of selectivity from using the panel component. Classifying observations into year of birth groups, education classes, or employment mode, we cannot reject the hypothesis that the marginal distributions of these variables from the overlap sample and the wave-1-only sample are independent. We do find strong country patterns, however, possibly indicating that data collection agencies in different countries achieved different response rates in the wave-2 data collection effort.
} 
Table 6: Average Age When First Drawn Some Pension Income or When Retired

\begin{tabular}{lrrrrrrr}
\hline \hline & \multicolumn{3}{c}{ age at first pension } & \multicolumn{3}{c}{ age at retirement } \\
country & self & all & wage & test & self & wage & new retirees \\
self & wage \\
\hline Austria & 58.5 & 57.3 & 0.0859 & 58.3 & 57.2 & $62.7^{*}$ & 58.4 \\
Belgium & 61.3 & 57.7 & 0.0000 & 61.9 & 59.2 & $62.0^{*}$ & 59.3 \\
Switzerland & 63.0 & 62.0 & 0.0825 & 64.2 & 62.1 & $65.5^{*}$ & $62.3^{*}$ \\
Germany & 60.8 & 60.0 & 0.0708 & 62.4 & 60.5 & $62.5^{*}$ & 62.2 \\
Denmark & 62.1 & 59.4 & 0.0280 & 63.4 & 62.6 & $63.5^{*}$ & 61.8 \\
Spain & 61.5 & 58.3 & 0.0033 & 62.1 & 59.6 & $63.8^{*}$ & 61.9 \\
France & 59.7 & 57.3 & 0.0005 & 60.1 & 58.1 & $61.1^{*}$ & 58.3 \\
Greece & 61.1 & 57.2 & 0.0000 & 61.0 & 57.1 & $62.0^{*}$ & $61.2^{*}$ \\
Italy & 56.7 & 55.8 & 0.0792 & 57.4 & 56.3 & $63.4^{*}$ & 59.3 \\
Netherlands & 60.5 & 56.5 & 0.0010 & 62.2 & 61.0 & $65.0^{*}$ & 61.1 \\
Sweden & 61.9 & 59.8 & 0.0068 & 61.2 & 61.4 & $60.9^{*}$ & 63.8 \\
\hline total & 59.6 & 58.2 & & 60.2 & 58.9 & 62.8 & 60.5 \\
\hline \hline
\end{tabular}

Notes: SHARE sample of retired male heads of households. Sample for 'age at retirement': individuals present in both waves. Column test refers to $p$-value of $t$-test that mean for self-employed exceeds mean for employees. ${ }^{*}:<20$ obs. Weighted statistics.

The average age when retiring ${ }^{20}$ in Table 6 follows closely the average age of drawing the first pension. The last columns of the Table consider new retirees, that is those that report to have retired between both sample waves. Age at retirement increases markedly for both self-employed and wage employees and the gap between both employment groups widens. The pattern points to the importance of recent increases in labor force participation, and the Table documents that this appears to be especially important for the selfemployed. Overall, the figures are consistent with a lower exit rate for the self-employed and for a decrease of that rate with time.

We confirm this explicitly by tracking labor market transitions in Table 7, where we attribute people to labor market status 'other' if they are disabled, out of the labor force or have some other non-classifiable status, but do not indicate that they work nonetheless. Whoever works is classified into employed or self-employed. ${ }^{21,22}$

Transitions into retirement are quite important, as is employment mode persistence among non-retirees. ${ }^{23}$ Both self-employed and wage employed have a three-quarter chance

\footnotetext{
${ }^{20}$ This information is available for wave-2 respondents.

${ }^{21}$ Note that we now exclude those from consideration that are self-employed in one out of two jobs. The latter information is unavailable in wave 2.

${ }^{22}$ The Table ignores job-to-job transitions and instances of serial self-employment.

${ }^{23}$ Recall that spacing between waves is not uniform across countries.
} 
Table 7: Labor Market Transitions (\%) between waves 1 and 2

\begin{tabular}{lrrrrrr}
\hline \hline Wave 1 & $\begin{array}{r}\text { self- } \\
\text { empl. }\end{array}$ & $\begin{array}{r}\text { wage } \\
\text { empl. }\end{array}$ & unemp. & other & retired & $\begin{array}{r}\text { total } \\
\text { (obs) }\end{array}$ \\
\hline self-employed & 74.17 & 7.68 & 0.53 & 1.85 & 15.76 & 755 \\
wage employed & 2.00 & 76.00 & 1.30 & 2.93 & 17.77 & 2,150 \\
unemployed & 4.89 & 22.22 & 32.89 & 10.67 & 29.33 & 225 \\
other & 2.16 & 7.79 & 1.73 & 51.08 & 37.23 & 231 \\
retired & 0.97 & 1.77 & 0.12 & 3.51 & 93.62 & 3,388 \\
\hline \hline
\end{tabular}

Notes: SHARE sample of male heads of households age 50-75, present in both waves. Cells contain row percentages, except last column (total number of observations); 'other' includes disabled and out of labor force. Unweighted statistics.

of staying what they are between waves, and in both cases about one sixth retires, with the self-employed being two percentage points less likely to retire. A self-employed worker is on average more likely to transition into wage employment than an employee would transition into self-employment.

Retirement is not entirely absorbing as a very limited number of people finds their way back into the labor market. The transition rates are heavily influenced by the age distribution, of course. Note however that of the handful of transitions back to work more than half are into self-employment.

\subsection{Institutional Variation in Social Security Legislation and Pensions}

Whereas the preceding tables have documented the large variation across countries in terms of labor market patterns and institutions in general, it is important to know in how far institutional arrangements differ for the self-employed vis-a-vis wage employed.

Table 8 gives a short account on coverage of self-employed in social security systems across the countries of interest. The differences between countries are too vast to be detailed in much depth (see for instance, Schoukens (2000) for a more comprehensive survey and European Commission (2001) for further institutional description). Broadly, in most countries the self-employeds' social insurance provisions are integrated in a national insurance system that also covers employees. In some countries, the self-employed are fully integrated (such as in Sweden), in others there are special provisions within the national system (such as Germany). A few countries have separate systems for the self-employed. Scandinavian systems are more easily characterized as being universal and compulsory: they tend to be tax-financed and eligibility is assessed by residence; there is typically no distinction between the employed and the self-employed. Similarly for the Netherlands, where social insurances are paid for by premia, and where some special insurances exist (or existed) for the self-employed (in particular disability). 
Table 8: Social Security for the Self-employed

\begin{tabular}{|c|c|c|c|c|c|c|c|c|}
\hline country & $\begin{array}{l}\text { general } \\
\text { system }\end{array}$ & $\begin{array}{l}\text { industry } \\
\text { specific }\end{array}$ & $\begin{array}{l}\text { unem- } \\
\text { ploym. }\end{array}$ & $\begin{array}{l}\text { employment } \\
\text { injuries }\end{array}$ & $\begin{array}{l}\text { disability, } \\
\text { invalidity }\end{array}$ & $\begin{array}{l}\text { old } \\
\text { age }\end{array}$ & $\begin{array}{l}\text { survivor } \\
\text { benefits }\end{array}$ & $\begin{array}{l}\text { long-term } \\
\text { care }\end{array}$ \\
\hline Austria & SSSE & AG, RT & $\begin{array}{l}\text { AG: n.a. } \\
\text { other: } \\
\text { voluntary }\end{array}$ & yes & $\begin{array}{l}\text { permanent } \\
\text { disability } \\
\text { only }\end{array}$ & $\begin{array}{l}\text { if } \\
\mathrm{cc} \\
\mathrm{b} \\
\mathrm{ta} \\
\mathrm{F}\end{array}$ & $\begin{array}{l}\text { yes; } \\
\text { if survivor } \\
\text { continues } \\
\text { business, } \\
\text { takes over } \\
\text { pension } \\
\text { claims }\end{array}$ & yes \\
\hline Belgium & SSSE & no & n.a. & n.a. & yes & yes & yes & $\mathrm{nsc}$ \\
\hline Switzerland & NI & no & n.a. & \multicolumn{5}{|c|}{$\begin{array}{l}\text { compulsory basic plan } \\
\text { voluntary } 2 \text { nd pillar }\end{array}$} \\
\hline Germany & SPNI & AG, RT & n.a. & yes & $\begin{array}{l}\text { yes; } \\
\text { AG: af }\end{array}$ & $\begin{array}{l}\text { yes; } \\
\text { RT: voluntary; } \\
\text { er business terminat }\end{array}$ & $\begin{array}{l}\text { yes; } \\
\text { ation }\end{array}$ & yes \\
\hline Denmark & NI & no & voluntary & $\begin{array}{l}\text { FI } \\
\text { only }\end{array}$ & yes & $\begin{array}{l}\text { yes; supplem. } \\
\text { plan: optional }\end{array}$ & yes & yes \\
\hline Spain & SSSE & AG & n.a. & $\begin{array}{l}\text { AG } \\
\text { only }\end{array}$ & partial & yes & yes & n.a \\
\hline France & SSSE & $\begin{array}{c}\text { AG, CR, } \\
\text { RT }\end{array}$ & n.a. & $\begin{array}{c}\text { AG } \\
\text { compulsory; } \\
\text { other: opt. }\end{array}$ & $\begin{array}{l}\text { industry } \\
\text { specific; } \\
\text { AG: unfit } \\
\text { for any } \\
\text { agr. work }\end{array}$ & yes & yes & $\mathrm{nsc}$ \\
\hline Greece & SSSE & AG, RT & n.a. & yes & yes & yes & yes & yes \\
\hline Italy & SPNI & no & n.a. & yes & yes & yes & yes & yes \\
\hline Netherlands & NI & no & n.a. & nsc & $\begin{array}{c}\text { yes } \\
\text { (special } \\
\text { system for } \\
\text { self-empl.) }\end{array}$ & yes & yes & yes \\
\hline Sweden & NI & no & voluntary & yes & yes & yes & yes &.$/$ \\
\hline
\end{tabular}

Sources: European Commission (2001); US Social Security Administration, website. Abbreviations: AG - agriculture; CR crafts; FI - fishing \& navigation; RT - retail NI - national, compulsory insurance with universal coverage SSSE - special system covering self-employed SPNI - special provisions for self-employed within national insurance system n.a. - risk not covered; nsc - risk not separately covered (no special plan) ./. - no information

Some countries differentiate treatment according to industry. In particular agriculture has special provisions. In terms of the main risks covered by social insurance (we disregard sickness and maternity provision in this overview), most countries also cover the self-employed, at least on an optional basis. An exception is, for instance, Belgium where employment-specific injuries or occupational hazards are not covered for the selfemployed, or Spain, where disability and invalidity insurances are less generous for the self-employed. Germany requires farmers to discontinue their businesses for benefit eligibility in the categories disability or invalidity, old age, and survivor's pensions. Retail business owners have the option of being covered under the German social security system. 
The largest difference between risks across countries concerns unemployment insurance. Possibly for reasons of moral hazard, unemployment (business termination due to, say, bankruptcy) is not covered for the self-employed, with the exceptions of Sweden, Denmark, and Austria. In Austria, farmers have their own social insurance fund which does not provide for covering unemployment risk. Self-employed in other occupations have the option of joining the general unemployment insurance, however. The Danish unemployment insurance is organized around occupational unemployment funds, which provide the self-employed with the option of joining. Likewise, Swedish self-employed may join the unemployment fund for their industry.

\section{Estimation Results}

We now turn to estimating regression models controlling for a number of relevant covariates. ${ }^{24}$ For the analyses in Sections 3.1 through 3.3 we rely on cross-sectional evidence. The time variation in the data is limited, preventing us from applying fixed effects (first difference) estimators here. In addition, not all variables available in wave 1 are also available in wave 2. When we consider actual transitions into retirement, in Section 3.4, we do exploit the panel feature of the data.

\subsection{Characterizing the Self-employed}

Table 9 displays marginal effects from probits of being self-employed in either primary or secondary job (the reference group is wage employed) for the working sample.

\section{Table 9 about here}

Columns 1-2 contain baseline estimates controlling for age, education, further demographics, wealth, income, country fixed effects, and industry.

Out of the 4,000 observations somewhat more than 1,000 are self-employed. The Pseudo$\mathrm{R}^{2}$ of around $16 \%$ indicates a reasonably good fit, compared to most of what is available elsewhere in the empirical literature; the self-employed are often hard to characterize in terms of observables.

\footnotetext{
${ }^{24}$ In what follows, all Tables with regression results are based on multiple imputation estimates to correct for the fact that there is uncertainty about any one imputed value. To help replicability, we use the multiply imputed values distributed by the data provider. The use of multiple imputation techniques does not change conclusions compared to using only singly imputed variables. $t$-values displayed are based on heteroskedasticity-robust standard errors. We apply a threshold value of at most $5 \%$ throughout when referring to 'significant' parameter estimates.
} 
We find a quadratic age effect. ${ }^{25}$ The overall pattern is that the probability of being self-employed increases with age in the sample, and in particular in age ranges beyond standard retirement age the likelihood of being self-employed becomes large. This accords with Figure 1.

Education coefficients seem to suggest that higher educated individuals are more likely to be self-employed. In particular in the group with the highest recorded education level the likelihood to be working for oneself is remarkably high. A Wald test also rejects that the education dummy variables as a group are insignificant.

Foreign-born individuals are $9 \%$ less likely to be self-employed, on average, than nativeborn. This finding is not consistent with the simple 'push' view that foreign-born workers are disadvantaged in domestic labor markets ${ }^{26}$ and select into self-employment because wage employment possibilities are difficult to obtain.

Marital status matters for being self-employed. Wald tests on joint siginficance show the dummy variable group to be jointly significant. Never-married single persons are $10 \%$ more likely to be self-employed than married or cohabiting individuals.

Private net worth is a strong correlate of being self-employed, as has been documented elsewhere. ${ }^{27}$ The presumption exists in the literature that either liquidity constraints make it hard for potentially self-employed to get started, so they need to accumulate wealth in order to build up collateral they can borrow against or that the self-employed have a larger saving rate (for instance, because they are less covered by public sector pension arrangements, not to speak of employer-sponsored or occupational pension schemes, or because of precautionary reasons). A million euros are associated with a 6 percentage points higher likelihood to be self-employed. We return to issues of potential endogeneity of wealth below, when we discuss other estimates and provide instrumental-variables estimates.

Lastly, income is also positively associated with being self-employed, but not significantly so. Income is household income of all members, net of the individual's own income from work or self-employment. ${ }^{28}$

We stratify the sample into 11 industries, with 'education and health' being the omitted category. We see from the estimates that almost all industry coefficients are positive, so being self-employed is least likely in public-sector industries. Agriculture (and mining),

\footnotetext{
${ }^{25}$ We have tried alternative specifications, using cubic age polynomials or splines. Using a parsimonious quadratic yields a relatively tight fit on the small age window.

${ }^{26}$ Bertrand and Mullainathan (2004) for instance, provide evidence for discrimination in labor markets.

${ }^{27}$ see, for instance, Gentry and Hubbard, 2004 or Hurst and Lusardi, 2004, and the references therein.

${ }^{28}$ Income may or may not be endogenous to being self-employed. We have no suitable instruments that allow a more precise assessment. Leaving income out of the equation, or including income from own work or self-employment, has negligible effects on the remaining coefficients and their standard errors, so that we believe there is no endogeneity bias.
} 
retail and wholesale, other services, and construction, are significantly more likely to be populated by self-employed workers. ${ }^{29}$

Country effects reflect the overall differences of self-employment rates between countries, as previously established in Table $2 .^{30}$

The cross-sectional patterns discussed here are correlates of self-employment and do not necessarily show causal effects of exogenous variation on self-employment. For instance, it is conceivable that there are strong selection effects present and that persons we observe to be self-employed at age 50 or above have different characteristics from those that ever entered self-employment. For instance, the education effects may reflect the skilled ones to survive in self-employment, whereas the unskilled ones return to wage employment. Whereas the descriptive evidence on the dynamics presented in Section 2.4 above points to high persistence, the data at hand do not allow an investigation of longrun effects and life cycle career paths.

We can at most include job tenure as a regressor. Results (not displayed) show, however, that tenure is not a statistically significant correlate of self-employment, once we condition on everything else.

Column 3-4 of Table 9 repeat the analysis but now also control for a number of other characteristics, such as occupation and job attributes, as well as expected pension claims. The regression is only included here for illustrative purposes as it uncovers a number of other important correlates of self-employment. For instance, we see that the self-employed are less likely to be associated with purely operative or elementary functions, and somewhat more associated with occupations of higher skill levels (the reference group is professionals). Occupation is correlated with education and here is where coefficient estimates are most affected.

Turning to job attributes that respondents could rate ${ }^{31}$ we find that many of the signs of the estimated marginal effects conform with intuition: being self-employed is strongly positively correlated with jobs that are physically demanding, offer little freedom, allow high skill development, give a high recognition, and offer poor job security. Being selfemployed is also strongly negatively correlated with jobs that offer adequate support in

\footnotetext{
${ }^{29}$ These patterns are broadly consistent with those for all ages, see OECD data, fn. 9.

${ }^{30}$ We have also estimated the models separately by country. Sample sizes are substantially lower. The overall fit of the regression equation differs strongly between countries (from $13 \%$ in Spain to $65 \%$ in Sweden), and coefficient estimates often do not line up between countries. This as such is not surprising, considering that self-employment rates between countries have a lot to do with differences in cultures and institutions that interact in complicated ways with personal characteristics.

${ }^{31}$ Each attribute is measured on a 4-point Likert scale from 'strongly agree' to 'strongly disagree' with certain statements; we display coefficients on dummy variables relating to 'strongly agree' and 'agree'. Ways of reducing the number of regressors have been considered by using factor analysis or constructing an index of job quality and effort-reward-imbalance (Siegrist et al., 2004). Results are available on request.
} 
difficult situations, or poor job advancement/promotion. There are no large differences between wage and self-employed when it comes to workload or remuneration.

The latter findings are intersting because we will show below that the self-employed work longer, but apparently their work load is not perceived particularly high. The indifference with respect to earnings is consistent with the nonsignificance of income noted above. Job attributes are possibly jointly chosen with self-employment, and we thus will not consider these in what follows.

Lastly, we use a number of indicators for possible future pension claims. Respondents could indicate a number of pension sources that they believe to be eligible for in the future, and we group them in to four nonexclusive categories (one of them is 'missing' which captures mainly don't know answers). The self-employed are less likely to have old age or early retirement pension eligibility, but are often not able to answer questions on eligiblity.

Column 5-6 of Table 9 are included for completeness. This is the specification we use later in some models when discussing selection effects. While the list of regressors differs slightly from the baseline, it is important to stress that between specifications the common parameter estimates and marginal effects are quite close to one another.

\subsection{Hours Worked}

Descriptive evidence provided in Section 2.4 above suggested that the self-employed work longer hours on average, and we confirm these patterns to hold even conditional on other observables, including, importantly, age and health. Table 10 displays results of linear regressions of the number of hours worked per week. ${ }^{32}$

\section{Table 10 about here}

Columns 1-2 is a baseline specification without controlling for industry. Again, there are about 4,000 observations, and the cross-sectional goodness of fit stastic is with $13 \%$ high by comparison. The self-employed work about 11 hours more per week than comparable employees. This is a substantial difference (the average is about 42 hours per week in the sample). Characteristics age, education, and other demographics, health, wealth, and country fixed effects cannot explain the difference away.

The age function indicates an increasingly decreasing labor supply with age, in line with expectations. Educational differences cannot be detected. Foreign-born individuals work less (on average, 2.7 hours less per week). Marital status is entirely unimportant.

\footnotetext{
${ }^{32}$ The estimated equation deviates from a standard labor supply function in that we do not condition on the hourly wage rate, which is not directly observed. In addition to issues of bias arising from using imputed hourly wage rates (Blundell and MaCurdy, 1999), empirical analysis for self-employed's labor supply may be complicated by the marginal wage not being fixed (Farber, 2005).
} 
As health measures we use an indicator of having a long-term illness, the number of chronic conditions (self-reported to have been) confirmed by a doctor, and the number of symptoms. In addition, we condition on the body mass index. In particular those with a long-term sickness work significantly less.

Country effects are very pronounced, respondents in all countries report (partly substantially) fewer hours than their counterparts in Germany, Austria and Switzerland.

Industry effects are likewise large. Not surprisingly, perhaps, is the finding that in all industries working hours are longer than in the reference category of education and health care (mostly public sector). Hours are particularly long in the self-employment prone industry of agriculture (and mining). Tenure is excluded but turned out to be insignificant.

The other columns in the Table present variations on the baseline, with the goodness of fit measure improving only slightly. This suggests that the baseline is a reasonable depiction of salient correlates of hours worked. The coefficient estimates of the baseline are typically not significantly altered, and standard errors stay in the neighborhood of baseline estimates.

Column 3-4 controls for occupation. Occupation is of course strongly correlated with both education and self-employment, and we see some, but no dramatic changes in the associated coefficient estimates. Managers (and workers in other administrative functions) work longer, as do farm workers; elementary operators and workers work less (all compared to professionals, the reference category).

Column 5-6 allows the self-employment indicator to be country-specific. In some countries the self-employed actually work less than in other countries (large negative and statistically significant coefficients are found for Spain, Switzerland, and Sweden). We take away from this that self-employment allows for substantial hours-worked flexibility.

The last columns in Table 10 exclude marital status but include income and wealth, compared to the baseline. Income appears to have a large positive effect.

We now consider the possibility that self-employment is potentially endogenous to hours worked. This could be the case, for instance, if unobserved characteristics that make individuals likely to work longer are also the ones that support a choice to be selfemployed. We apply techniques that are particularly useful to study observational (nonexperimental) data.

We pursue two different empirical strategies. One is direct instrumentation of an endogenous dummy variable (IV). The other is allowing self-employed and wage-employed workers to have different coefficient estimates while modeling the self-employment choice. This type of model is known as endogenous switching regressions model (see for instance, Maddala, 1983). It accounts (and hence corrects) for the fact that a difference in hours is partly generated by certain types sorting into self-employment. 
Underlying the employment dummy $s$ is a stochastic process that determines employment mode: a person $i$ is self-employed whenever the latent variable $s^{\star}$ exceeds some threshold value. This latent variable is modeled by a function of observable characteristics $z$ and an error term $\varepsilon$,

$$
s_{i}^{\star}=z_{i}^{\prime} \gamma+\varepsilon_{i} .
$$

The observability rule is

$$
s_{i}=\mathbf{1}\left[s_{i}^{\star}>0\right]
$$

where $\mathbf{1}[A]$ is the $0 / 1$ indicator function taking value 1 whenever expression $A$ is true.

The instrumental variable model can be estimated by full information maximum likelihood, estimating jointly equation (1) and the hours worked equation,

$$
h_{i}=x_{i}^{\prime} \beta+s_{i} \delta+v_{i} .
$$

Instrumentation of $s_{i}$ requires exclusion restrictions for nonparametric identification. We rely on marital status and wealth that have been shown earlier to matter for self-employment (Table 9) but not for hours worked (Table 10). Results are in the first columns of Table 11.

\section{Table 11 about here}

Instead of discussing particular coefficient estimates in greater detail it suffices to point out the high stability compared to the uninstrumented case. We find a significant negative coefficient on instrumented self-employment in the hours worked equation (the coefficient drops from 10.9 to 8.8 hours), but cannot reject the hypothesis that equations (1) and (2) are independent. ${ }^{33}$

The switching regressions model is a more flexible generalization that postulates that hours worked are generated from two different distributions, according to whether a person is wage or self-employed. Hours worked is then one of two types, $s=0,1, h_{1}$ for a self-employed individual and $h_{0}$ for a wage employed person. Each $h_{s}$ is described by its own statistical model, and selection into group $s$ is governed by the selection equation (1). The hours equation then depends on the chosen type $s$ :

$$
h_{s i}=x_{i}^{\prime} \beta_{s}+v_{s i}, \quad s=0,1 .
$$

So, while there are two potential outcomes, $h_{0}$ and $h_{1}$, for each individual, only one of them is actually observed in the data, according to

$$
h_{i}=\left\{\begin{array}{ll}
h_{0 i} & \text { if } s_{i}^{\star} \leq 0 \\
h_{1 i} & \text { if } s_{i}^{\star}>0
\end{array} .\right.
$$

\footnotetext{
${ }^{33}$ We have alternatively also used a linear IV model which we estimate by GMM to allow for a very general error structure. The self-employment equation is a linear probability model. Results are available on request.
} 
Importantly, the selection mechanism governing the choice of regime depends on unobservables. It models the non-random decision to join one regime rather than the other. The error distributions need not be identical between regimes (nor between individuals of the same regime). To estimate the model, we shall assume that the vector $\xi_{i}=\left(v_{0 i}, v_{1 i}, \varepsilon_{i}\right)$ for person $i$ follows a trivariate normal distribution with suitable restrictions on the covariance matrix to achieve identification (the variance of $\varepsilon_{i}$ is set to unity and the correlation between $v_{0 i}$ and $v_{1 i}$ is set to zero). All $\xi_{i}$ are independently distributed. We may wish to allow for nonidentical distributions between individuals to account for heteroskedasticity. Exclusion restrictions are the same as before. ${ }^{34}$

Mean hours of self-employed who selected into self-employment can be calculated as

$$
E\left(h_{1} \mid s=1\right)=E\left(h_{1} \mid s^{\star}>0\right)=E\left(h_{1} \mid \varepsilon>-z^{\prime} \gamma\right)=x_{1} \beta_{1}+\sigma_{1 \varepsilon} \frac{\phi\left(z^{\prime} \gamma\right)}{\Phi\left(z^{\prime} \gamma\right)}
$$

whereas mean hours of wage employed who selected into wage employment are

$$
E\left(h_{0} \mid s=0\right)=E\left(h_{0} \mid s^{\star} \leq 0\right)=E\left(h_{0} \mid \varepsilon \leq-z^{\prime} \gamma\right)=x_{0} \beta_{0}-\sigma_{0 \varepsilon} \frac{\phi\left(z^{\prime} \gamma\right)}{1-\Phi\left(z^{\prime} \gamma\right)} .
$$

The model allows calculating counterfactual conditional means, i.e., determining the expected hours worked for a wage employee (someone with wage employed coefficients) had he been made to become self-employed,

$$
E\left(h_{0} \mid s=1\right)=E\left(h_{0} \mid s^{\star}>0\right)=E\left(h_{0} \mid \varepsilon>-z^{\prime} \gamma\right)=x_{0} \beta_{0}+\sigma_{0 \varepsilon} \frac{\phi\left(z^{\prime} \gamma\right)}{\Phi\left(z^{\prime} \gamma\right)}
$$

or the mean hours that someone with self-employed coefficients would supply in wage employment ${ }^{35}$

$$
E\left(h_{1} \mid s=0\right)=E\left(h_{1} \mid s^{\star} \leq 0\right)=E\left(h_{1} \mid \varepsilon \leq-z^{\prime} \gamma\right)=x_{1} \beta_{1}-\sigma_{1 \varepsilon} \frac{\phi\left(z^{\prime} \gamma\right)}{1-\Phi\left(z^{\prime} \gamma\right)} .
$$

Results show that wage employed and self-employed differ in the observed determinants of hours worked, as well as in the estimated error distributions. The variance is much larger for the self-employed, and the correlation between (1) and the self-employment hours equation in (3) is quite large and significant: the unobservables that make someone more likely to be self-employed also increase hours supplied.

The signs of the estimated correlations show that expected selectivity-corrected hours of wage employees are larger than the population mean (the mean number of hours supplied by a person that were randomly drawn from the wage employee population without

\footnotetext{
${ }^{34}$ We have also considered variations in which a subset or all of the elements of $\beta_{S}$ are constrained to be equal across types $s$. If only the intercept differs, the model reduces to the IV model discussed earlier.

${ }^{35}$ Martinez-Granado (2005) estimates such a model for hours in a different context using GMM and panel data. The common ground with her paper is the assumption that the underlying distributions of hours worked are different for two observable but self-chosen subgroups in the population, prominently through the added flexibility of labor supply that membership of one of the two groups affords.
} 
it being given the choice in which sector to work), and the mean hours supplied by selfemployed is again larger than the population mean, indicating positive selection. The estimate of the hours differential conditional on their self-selected respective employment states equals 10.4 hours ((4)-(5)). The counterfactual means suggest that someone who is actually observed to be self-employed would work 11 hours less in wage employment than in self-employment ((4)-(6)). ${ }^{36}$ Such pronounced differences are remarkable, and can possibly be reconciled with the existence of specific returns to self-employment that selfemployment affords.

\subsection{Retirement Reasons and Retirement Wishes}

Table 12 investigates for the retiree sample in how far there are differences between former self-employed and wage employees when it comes to reasons for having retired in the past. The question probed asked 'for which reasons did you retire', and there were 10 explicit reasons mentioned, plus a residual category 'other'. These reasons are displayed in the Table. Multiple answers were allowed, although most respondents chose a single reason.

\section{Table 12 about here}

We estimate separate probit models, controlling for many of the important characteristics that we include elsewhere, to the extent that these are available for the sample (among which, demographics, health status, wealth, pension income, country dummies). The Table only displays the marginal effect of the self-employment dummy variable on the outcome probability. ${ }^{37}$ Interesting differences with the group of wage employees can be found: the self-employed are 5 percentage points more likely to retire for each reason of 'own ill health' and 'to enjoy life'. They are also more likely to retire at the same time as their spouse or partner, or to spend time with their families (these latter two effects are only significantly different from zero at the $10 \%$ level, however). In addition, they are more likely to retire for other reasons than those mentioned explicitly. We interpret these results as evidence that self-employment offers substantial degrees of freedom when it comes to choosing the date of retirement.

Country dummies show the strongest marginal effects. For instance, placing a person with average characteristics from Germany to Denmark would decrease his probability

\footnotetext{
${ }^{36}$ Results are unaffected if we do not condition on occupation, or restrict certain coefficients in (1), such as health and occupation, to zero. Results also do not change appreciably if we do not use wealth as an exclusion restriction or leave it out altogether.

${ }^{37}$ We have also estimated multinomial models. Due to the large number of motives and the small amounts of observations in some of the multiple-answer cells, substantial aggregation of motives was called for. Exploratory results can be obtained on request.
} 
of retiring for eligibility of public pension schemes by 29 percentage points; placing him instead to Austria would increase this probability by 31 percentage points.

We also allow for country-specific differences between wage employees and self-employed. Instead of displaying separate marginal effects the Table provides the $p$-value of a Wald test of joint significance of coefficients as a summary measure. Reasons where we can expect differences across countries due to institutional variation (pension arrangements, health systems) show a low $p$-value. Reasons that are more associated with preferences (care for ill health of relatives or friends, to spend more time with family, and to 'enjoy life') do not exhibit significant variation across countries, however.

Conversely, we can consider the group of working individuals and probe whether they want to retire 'as early as [they] can' from their current job. While this statement does not make explicit possible trade-offs in terms of financial incentives for earlier or later retirement, it is indicative of 'work ethics' or attachment to work, once we control for other job-related characteristics, demographics, and country. Table 13 presents marginal effects from four variations of a probit equation.

\section{Table 13 about here}

Columns 1-2 present the baseline case where we condition on age, demographics, health, income, wealth and country dummies. Being self-employed as such reduces the wish to retire as early as possible by ten percentage points. This is a very substantial difference. Age correlates negatively with wishing to retire as early as possible, indicating the importance of the retirement horizon in the face of mostly actuarially unfair retirement systems (the further respondents are removed from standard retirement age, the more inclined they are to retire early). The education gradient is very pronounced-the more educated the less the desire for early retirement. Marital status (singles do not wish to retire as early as couples), and health (the sick want to leave early) score importantly and significantly. Neither wealth nor income matters. These findings are fully robust to inclusion of industry and occupation effects (columns 3-4).

The remaining columns are to be understood of exploratory analyses that probe further correlations of interest. Including in addition job characteristics (as well as hours worked) reduces the marginal effect of self-employment to minus seven percentage points, see columns 5-6. People that are very satisfied with their jobs have a 25 percentage point lower probability to wish to retire as early as possible. Further, jobs that are giving a freer choice of how to work, and that provide recognition of one's efforts are associated with sometimes markedly lower probabilities to wishing to retire as early as possible. Conversely, heavy jobs induce the wish to withdraw early. Interestingly, it is unimportant 
whether the job held offers good or bad job security. ${ }^{38}$ Finally, those that work longer hours are slightly less likely to want to retire early. Together with the industry and occupation dummies, these results strongly suggest that work characteristics are an important driving force of the desire to leave into retirement.

Columns 7-8, finally, also include future pension claim expectations. Those that are eligible to retire early also say they wish to retire early. The estimate on self-employment is only slightly affected, many other coefficients are largely unaffected.

What all this suggests is that the self-employed are attached to work beyond being in a favorable environment, and other observables. These results are hence in line with the earlier findings of the switching regressions model on hours worked.

\subsection{Retirement Behavior}

To analyze actual retirement, we use wave- 2 information on year and month of retirement. The sample conditions on those working in the first wave. We flag those that report in the second wave a date of retirement that lies after the interview of the first wave. This applies to nearly $13 \%{ }^{39}$ Table 14 shows results for a choice of specifications.

\section{Table 14 about here}

The baseline (columns 1-2) conditions on age, demographics, health, income and wealth, and again on country dummies. The regression function is very well determined with a Pseudo- $R^{2}$ of $27 \%$. The self-employed are on average four percentage points less likely to retire, conditional on all included observables. Given the base of $13 \%$, this is a very substantial effect. Age effects are in line with expectations and drive much of the fit of the model. The highest educated retire latests. Marital status and health are strong predictors, as we had also found in earlier analyses (Tables 12 and 13). Health variables are jointly significant, and the number of illness symptoms is positively associated with a retirement decision. The magnitude is small, however.

Modeling work by Wooley (2005) suggests that higher wealth holdings (relative to earnings) can be predicted to be a prime determinant of retirement transition: the wealthier retire earlier as wealth affords enjoying leisure during retirement (while forgoing earnings). Our results suggest, however, that wealth does not matter, quite in line with the empirical finding in Wooley (2005). ${ }^{40}$

Columns 3-4 deviate from the definition of a newly retired person and only flag those

\footnotetext{
${ }^{38}$ These findings also are robust to a full interaction of self-employment with all job characteristics.

${ }^{39}$ Note that the interview dates, and hence the spacing between interviews, differs somewhat between countries, but results are unchanged if we explicitly condition on interview quarter.

${ }^{40}$ In his case, retirement is determined entirely in the cross-section.
} 
that in wave 2 do not say they work for money despite considering themselves retired. This definition makes a difference to parameter estimates, and the marginal effect of being self-employed changes to -1.8 percentage points. Since the base is diminished as well (only $4.5 \%$ of wave- 1 respondents retire completely from activity between waves), the relative effect for the self-employed is actually stronger, in line with expectations on flexibility of continued work reported above.

Column 5-6 return to the baseline sample of columns 1-2 but adds industry dummies, pension claim expectations and self-employment/country interactions. The latter allow for additional flexibility to capture institutional differences in retirement systems between the wage employed and self-employed. These interaction terms are significant as a group. There is evidence that especially the interaction term for Italian self-employed is strongly significantly negative. This is consistent with the institutional setting in Italy where retirement incentives for wage earners in particular are strong, but not for the self-employed. ${ }^{41}$

Adding occupational dummies or job characteristics appears not to be empirically important (results are not included in the Table), unlike in the assessment of the wish to retire early, Table 13. This points to a deviation between wishes and realizations. In the end, it is institutions and age that determine retirement and not correlates of retirement preferences. We have also allowed for country-specific age profiles in auxiliary regressions. We found them to be significant for only two countries (Sweden and Denmark).

Wealth is possibly endogenous to retirement. Life-cycle wealth accumulation will be jointly chosen with life-cycle labor supply and retirement decisions, and saving partly occurs in order to finance consumption during retirement (Diamond and Hausman, 1984). Brown et al. (2010), for instance, suggest to use shocks to wealth (unexpected receipt of inheritances) in order to study a revision of the retirement decision.

Instruments are hard to come by. We have used regional statistics published by OECD on, for instance, GDP growth, but found them not to be highly correlated with wealth. Regional house price indexes only exist for selected countries and not on a comparable basis. Instead, we rely on predicted home values. These are based on regressions of observed home values of home owners in our sample on observable home characteristics, and subsequently averaged per NUTS area. As instruments we then use these averaged predicted home values, an indicator of whether the household lives in a big city, and the

\footnotetext{
${ }^{41}$ The marginal effects displayed in Table 14 are simple differences in probabilities for the cases where the interaction effect (itself being a 0/1 dummy variable) is switched on or off. In nonlinear models such as the probit these magnitudes do not necessarily correspond to analytical marginal interaction effects, which vary in the sample and depend on the data (e.g., Greene, 2010). Instead, we have checked the coefficient estimates in the probit and in a linear probability model to come to our conclusion, and do not emphasize other 'significant' interaction terms in the Table.
} 
interaction of both. ${ }^{42}$ We find the instruments to be jointly significant predictors, without the hypothesis of exogeneity being rejected. Column 7-8 show the associated second stage marginal effects for completeness, but we abstain from further discussion.

\subsection{Sensitivity Analyses}

We offer a brief account of additional sensitivity analyses conducted without displaying detailed results. Importantly, the estimates are robust to changes in specifciations.

Self-employment. The definition of self-employment is entirely based on self-reports, and there are no alternatives in the data. The measure entertained in the analyses might slightly overcount the self-employed to the extent that there are people that have a main job as a wage earner and are involved in, say, marginal freelance activities in a secondary job. It might also blur the estimates obtained as the environmental parameters pertaining to wage earners could be more relevant for this particular group (which is limited in size, however, see Table 2).

The results are largely unaffected when excluding the second-job self-employed, across the various analyses that we have presented so far. One difference concerns a slightly lower self-employment coefficient in the hours worked equation. There is no effect on the retirement transition, however.

Health. We chose to measure health by self-reported, but interpersonally comparable measures. Among the alternative measures available features a self-reported summary classification of general health, on a five-point categorical scale ('would you say your health is: (1) excellent...(5) poor.'). We use four dummy variables. Results for the health measure coefficients conform with expectations, and virtually all other parameter estimates in other regressions are unaffected. Such measures are standard in the literature but have recently come under attack by the criticism of lacking interpersonal comparability (Salomon et al., 2004).

The number of limitations in activities of daily living (ADL, e.g. 'walking across a room') and in instrumental ADL (e.g. 'managing money') have also been considered. These are often more relevant for the already retired population, and those that are retiring. Number of limitations in ADL are correlated with our number of symptoms measure and point in the same direction.

The retirement transition regression (Table 14) has also been estimated using changes in the health measures that we used earlier. The explanatory power of these is rather low, however. Parameters of interest are unaffected.

\footnotetext{
${ }^{42}$ First stage results are available on request.
} 
Wealth. The wealth measure chosen in this paper is private (non-business) net worth, which is the relevant margin when studying decisions of hours worked, for instance, where we relate labor supply behavior to resources available for consumption purposes. Total net worth including business wealth is perhaps more relevant for the retirement margin. We find no important differences, however. Inspection of the imputed business wealth variable reveals a large number of zero values among the self-employed, and it is not clear how well the variable actually captures business equity.

\section{Conclusions}

This paper offers a comprehensive and judicious descriptive analysis of labor supply and retirement behavior of the self-employed vis-a-vis the wage employed. The data is drawn from the pan-European SHARE survey that samples the population of residents born before 1955 in eleven different countries. We focus on male heads of households in the age range 50-75.

Institutional differences between the various countries in terms of incentives for labor force market behavior at the end of the working life cycle are arguably large and important. Social security and old-age pension systems differ not only across countries but also within countries for the wage employed and the self-employed.

We find that self-employment at older working ages offers substantial flexibility in many regards. The hours-worked distribution of the self-employed is substantially less spiked than that of wage employees, spans a much wider range and has a much larger variance. The self-employed work on average a good 10 more hours per week and are more than 4 percentage points less likely to retire in the span of 2 years than observationally equivalent wage workers. These findings survive when we control for individual characteristics capturing preferences and circumstances, for economic resources, and for institutional variation that is afforded by our multi-country data source.

An endogenous switching regression model suggests a strong effect-mainly via unobservables-of self-selection of certain types of individuals to choose self-employment and to (subsequently) supply more hours.

The analysis of retirement behavior reveals that the definition of retirement plays some role. We can consider whether we include among the retirees those that continue working for money (while, for instance, drawing pension income). Self-employment is particularly important for this group, and less so for those that are going to stop working altogether. A residual effect survives even here. The remaining variation may possibly be attributable to unobserved factors such as work ethic, or otherwise strong attachment to work and business (or a low elasticity of intertemporal substitution) as prime candidates for determining 
the self-employeds' life cycle labor supply behavior.

Job tenure information provides evidence that the self-employed in the sample have chosen their employment mode already early on in life, and have been successful in their entrepreneurial endeavours. For future research it will be important to understand the role of unobservables in the dynamic selection into entrepreneurship and the implication of business survival for retirement behavior. Our evidence is consistent with positive selection on unobservables of hard-working individuals into self-employment, which at the same time is conducive to survival in self-employment, a large supply of hours to the market, and work until late in life. Corroborative evidence could come from long panel data. Understanding these pathways is important for policy conclusions.

\section{References}

Berkovec, James, and Steven Stern (1991): “Job Exit Behavior of Older Men," Econometrica, $59,189-210$.

Bertrand, Marianne, and Sendhil Mullainathan (2004): “Are Emily and Greg More Employable Than Lakisha and Jamal? A Field Experiment on Labor Market Discrimination," American Economic Review, 94, 991-1013.

Blanchflower, David G. and Andrew Oswald (1998): "What makes an entrepreneur?," Journal of Labor Economics, 16, 26-60.

Blanchflower, David G. (2000): "Self-Employment in OECD Countries," Labour Economics, 7, 471-505.

Blau, David M. (1994): “Labor Force Dynamics of Older Men,” Econometrica, 62, 117-156.

Blöndal, Sveinbjörn, and Stefano Scarpetta (1999): "The Retirement Decision in OECD Countries," OECD Economics Department Working Paper \#202.

Blundell, Richard and Thomas MaCurdy (1999): "Labor Supply: A Review of Alternative Approaches," chapter 27 in Handbook of Labor Economics, Vol. 3A, ed. by Orley C. Ashenfelter and David Card. Amsterdam: North-Holland, 1559-1695.

Brown, Jeffrey R., Courtney C. Coile, and Scott J. Weisbenner (2010): “The Effect of Inheritance Receipt on Retirement," Review of Economics and Statistics, 92, 425-434.

Diamond, Peter A., and Jerry A. Hausman (1984): “Individual Retirement and Savings Behavior," Journal of Public Economics, 23, 81-114.

Dickens, William T. and Shelly J. Lundberg (1993): "Hours Restrictions and Labor Supply," International Economic Review, 34, 169-192.

Duval, Romain (2003): "Retirement Behavior in OECD Countries: Impact of Old-age Pension Schemes and Other Social Transfer Programs," OECD Economic Studies, 37, 7-50. 
European Commission (2001): "Mutual Information System on Social Protection in the EU Member States and the EEA (MISSOC). Annex 2: Social Protection of the Selfemployed," Brussels: European Commission.

Euwals, Rob, Daniel van Vuuren, and Ronald Wolthoff (2005): "Early Retirement Behaviour in the Netherlands: Evidence from a Policy Reform," CPB The Hague, mimeo.

Evans, David S. and Boyan Jovanovic (1989) “An estimated model of entrepreneurial choice under liquidity constraints," Journal of Political Economy, 97, 808-827.

Farber, Henry S. (2005): “Is Tomorrow Another Day? The Labor Supply of New York City Cabdrivers," Journal of Political Economy, 113, 46-82.

Fuchs, Victor (1982): "Self-employment and Labor Force Participation of Older Males," Journal of Human Resources, 17, 339-357.

Gentry, William M. and R. Glenn Hubbard (2004): “Entrepreneurship and Household Saving," Advances in Economic Analysis \& Policy, 4, Article 8.

Greene, William H. (2003): “Testing Hypotheses about Interaction Terms in Nonlinear Models," Economics Letters, 107, 291-296.

Gruber, Jonathan, and David Wise (1998): "Social Security and Retirement: An International Comparison," American Economic Review, Papers and Proceedings, 88(2), 158-163.

Gruber, Jonathan, and David Wise (2004): "Introduction and Summary," in Jonathan Gruber and David A. Wise, eds, Social Security Programs and Retirement around the World: Micro Estimation. Chicago: University of Chicago Press, pp. 1-40.

Gustman, Alan L., and Thomas L. Steinmeier (1984): "Partial Retirement and the Analysis of Retirement Behvior," Industrial and Labor Relations Review, 37, 403-415.

Gustman, Alan L. and Thomas Steinmeier (2001): "Retirement and Wealth," Social Security Bulletin, 64, 66-91.

Haider, Steven J. and David S. Loughran (2010): “Elderly Labor Supply: Work or Play?" in K. Christensen and B. Schneider (eds.), Workplace Flexibility: Realigning 20th Century Jobs to 21st Century Workers. Ithaca, NY: Cornell University Press.

Hamilton, B. H. (2000): “Does Entrepreneurship Pay? An Empirical Analysis of the Return to Self-employment," Journal of Political Economy, 108, 604-631.

Holtz-Eakin, Douglas, David Joulfaian, and Harvey S. Rosen (1994): “Sticking it out: entrepreneurial survival and liquidity constraints," Journal of Political Economy, 102, $53-75$.

Hurst, Eric and Annamaria Lusardi (2004): "Liquidity Constraints, Household Wealth, and Entrepreneurship," Journal of Political Economy, 112, 319-347.

Maddala, G.S. (1983): Limited-Dependent and Qualitative Variables in Econometrics. Cambridge: Cambridge University Press. 
Maestas, Nicole (2010): “Back to Work: Expectations and Realizations of Work after Retirement," Journal of Human Resources, 45, 718-748.

Martinez-Granado, Maite (2005): “Testing labour supply and hours constraints," Labour Economics, 12, 321-343.

Meghir, Costas and Edward Whitehouse (1997): "Labour Market Transitions and Retirement of Men in the UK," Journal of Econometrics, 79, 327-354.

OECD (2004): Employment Outlook. Paris: OECD.

Parker, Simon C. and Martin T. Robson (2004): "Explaining International Variations in Entrepreneurship: Evidence From a Panel of OECD Countries," Southern Economic Journal, 71, 287-301.

Parker, Simon C. and Jonathan Rougier (2007): "The Retirement Behaviour of the Selfemployed in Britain," Applied Economics, 39, 697-713.

Peracchi, Franco, and Finis Welch (1994): "Trends in Labor Force Transitions of Older Men and Women," Journal of Labor Economics, 12, 210-242.

Quinn, Joseph F. (1980): “Labor-force participation patterns of older self-employed workers," Social Security Bulletin, 43(4), 17-28.

Ruhm, Christopher J. (1990): "Bridge Jobs and Partial Retirement," Journal of Labor Economics, 8, 482-501.

Salomon, Joshua A., Ajay Tandon, and Christopher L. Murray (2004): “Comparability of Self Related Health: Cross Sectional Multi-Country Survey Using Anchoring Vignettes," British Medical Journal, 328, 258-264.

Schoukens, Paul (2000): “Comparison of the Social Security Law for Self-employed Persons in the Member States of the European Union," in Danny Pieters (ed.), Changing Work Patterns and Social Security. EISS Yearbook 1999. London: Kluwer Law International, 63-98.

Siegrist, Johannes, Dagmar Starke, Tarani Chandola, Isabelle Godin, Michael Marmot, Isabelle Niedhammer, Richard Peter (2004): "The measurement of effort-reward imbalance at work: European comparisons," Social Science E Medicine, 58, 1483-1499.

Stock, J.H. and D.A. Wise (1990): "Pensions, the Option Value of Work, and Retirement," Econometrica, 58, 1151-1180.

Taylor, Mark P. (1999): "Survival of the Fittest? An Anlysis of Self-employment Duration in Britain," Economic Journal, 109, C140-C155.

Woolley, Matthew (2005): Essays on Life-Cycle Portfolio Choice with Endogenous Retirement. Doctoral Dissertation, Department of Economics, University of North Carolina at Chapel Hill. 


\section{Software}

Koehler, Walter, Alois Kneip and Eva Herrmann (1997): "glkern .f and lokern.f: kernel regression estimation with automatically adapted global bandwidth or local bandwidth array," Version 10.1.1997, University of Zurich.

Lokshin, M. and Z. Sajaia (2008): "movestay . ado: Maximum-likelihood estimation of endogenous switching regression models," Version 3.0.2, 21 Apr 2008, Stata Journal, 4 (2004), 282-289.

Robinson, David T. and Dan Blanchette (2009): "rii.ado: Repeated-Imputation Inference," Version 1.0.1, 09 Oct 2009, Duke University. 


\section{A Tables}

Table 9: Self-employment and Characteristics

\begin{tabular}{|c|c|c|c|c|c|c|}
\hline \multirow[b]{2}{*}{ variable } & \multicolumn{2}{|c|}{ baseline } & \multicolumn{2}{|c|}{ full } & \multicolumn{2}{|c|}{ selection } \\
\hline & marg.eff. & $t$-value & marg.eff. & $t$-value & marg.eff. & $t$-value \\
\hline age & -0.1250 & -3.39 & -0.0890 & -2.58 & -0.1149 & -3.14 \\
\hline $\operatorname{age}^{2} / 100$ & 0.1182 & 3.68 & 0.0852 & 2.83 & 0.1092 & 3.42 \\
\hline edu.: (lower) secondary & 0.0344 & 1.34 & 0.0309 & 1.20 & 0.0330 & 1.26 \\
\hline edu.: (upper) secondary & 0.0133 & 0.58 & -0.0115 & -0.50 & -0.0141 & -0.61 \\
\hline edu.: post-sec., non-tertiary & 0.0388 & 0.83 & -0.0164 & -0.38 & 0.0090 & 0.19 \\
\hline edu.: 1st tertiary & 0.0615 & 2.41 & -0.0125 & -0.47 & -0.0018 & -0.07 \\
\hline edu.: 2nd tertiary & 0.2155 & 2.57 & 0.0634 & 0.80 & 0.1504 & 1.84 \\
\hline edu.: other & 0.0523 & 0.63 & 0.0244 & 0.27 & 0.0149 & 0.18 \\
\hline foreign-born & -0.0923 & -3.82 & -0.0773 & -3.37 & -0.0804 & -3.24 \\
\hline household size & 0.0165 & 2.21 & 0.0171 & 2.28 & 0.0182 & 2.45 \\
\hline marital st.: nvr. married & 0.1014 & 2.82 & 0.1269 & 3.26 & 0.1032 & 2.77 \\
\hline marital st.: widowed & 0.0179 & 0.33 & -0.0170 & -0.33 & 0.0213 & 0.38 \\
\hline marital st.: div./sep. & 0.0495 & 1.62 & 0.0682 & 2.09 & 0.0661 & 2.07 \\
\hline private net worth (m EUR) & 0.0564 & 3.88 & 0.0420 & 3.77 & 0.0504 & 3.86 \\
\hline other hh income (100k EUR) & 0.0068 & 1.31 & 0.0028 & 0.72 & 0.0045 & 0.96 \\
\hline long-term sickness & & & & & 0.0214 & 1.20 \\
\hline number of chronic conditions & & & & & -0.0100 & -1.19 \\
\hline number of symptoms & & & & & -0.0092 & -1.15 \\
\hline body mass index & & & & & 0.0002 & 0.13 \\
\hline Austria & -0.0034 & -0.09 & 0.0173 & 0.44 & 0.0117 & 0.29 \\
\hline Belgium & -0.0425 & -1.49 & -0.0496 & -1.82 & -0.0529 & -1.90 \\
\hline Switzerland & 0.1062 & 2.39 & 0.1111 & 2.28 & 0.0559 & 1.30 \\
\hline Denmark & -0.0567 & -1.86 & 0.0926 & 1.79 & -0.0444 & -1.42 \\
\hline Spain & 0.0206 & 0.54 & 0.0555 & 1.32 & 0.0048 & 0.13 \\
\hline France & -0.0774 & -2.79 & -0.0364 & -1.18 & -0.0726 & -2.62 \\
\hline Greece & 0.1369 & 3.80 & 0.1463 & 3.79 & 0.1541 & 4.04 \\
\hline Italy & 0.1680 & 3.95 & 0.1483 & 3.40 & 0.1691 & 3.90 \\
\hline Netherlands & -0.1175 & -4.71 & -0.0904 & -2.92 & -0.1060 & -4.20 \\
\hline Sweden & -0.0717 & -2.89 & -0.0848 & -3.44 & -0.0781 & -3.18 \\
\hline ind.: missing & 0.4491 & 12.66 & 0.4226 & 8.73 & 0.4812 & 11.53 \\
\hline ind.: other & -0.0638 & -0.97 & -0.0360 & -0.55 & -0.0617 & -0.96 \\
\hline ind.: agriculture \& mining & 0.4692 & 7.97 & 0.3009 & 3.87 & 0.3522 & 4.79 \\
\hline ind.: manuf., low tech & 0.0952 & 2.69 & 0.0891 & 2.25 & 0.1299 & 3.31 \\
\hline ind.: manuf., high tech & 0.0411 & 0.94 & 0.0315 & 0.71 & 0.0619 & 1.31 \\
\hline ind.: supplies \& construction & 0.1661 & 4.46 & 0.0970 & 2.40 & 0.1565 & 3.88 \\
\hline ind.: wholesale, retail & 0.3872 & 10.27 & 0.3177 & 6.80 & 0.3606 & 8.53 \\
\hline ind.: transp., comm., finance & 0.0429 & 1.22 & 0.1153 & 2.67 & 0.1338 & 3.23 \\
\hline ind.: other sophisticated & 0.0440 & 1.37 & 0.0544 & 1.59 & 0.0530 & 1.60 \\
\hline ind.: other services & 0.2530 & 5.31 & 0.2600 & 4.82 & 0.2949 & 5.85 \\
\hline occ.: missing & & & -0.1519 & -8.27 & -0.1530 & -6.30 \\
\hline occ.: other, inc. armed forces & & & -0.1248 & -3.63 & -0.1531 & -4.42 \\
\hline occ.: admin./managerial & & & 0.0466 & 1.75 & 0.0658 & 2.46 \\
\hline occ.: technicians & & & -0.0556 & -2.39 & -0.0530 & -2.22 \\
\hline occ.: clerks & & & -0.1947 & -15.69 & -0.2271 & -18.77 \\
\hline occ.: service/sales workers & & & -0.0803 & -2.85 & -0.0965 & -3.35 \\
\hline
\end{tabular}


Table 9: Self-employment and Characteristics (continued)

baseline full selection

\begin{tabular}{|c|c|c|c|c|c|}
\hline variable & marg.eff. $\quad t$-value & marg.eff. & $t$-value & marg.eff. & $t$-value \\
\hline occ.: skilled farm worker & & 0.1799 & 2.77 & 0.1881 & 3.10 \\
\hline occ.: craftsmen & & -0.0310 & -1.11 & -0.0403 & -1.49 \\
\hline occ.: operators & & -0.1226 & -5.72 & -0.1546 & -7.76 \\
\hline occ.: elementary occupations & & -0.1518 & -8.09 & -0.1761 & -9.17 \\
\hline job: v. satisfied & & -0.0313 & -1.07 & & \\
\hline job: satisfied & & -0.0408 & -1.50 & & \\
\hline job: v. phys. demanding & & 0.0979 & 4.09 & & \\
\hline job: phys. demanding & & 0.0743 & 3.81 & & \\
\hline job: v. heavy workload & & 0.0245 & 1.22 & & \\
\hline job: heavy workload & & 0.0339 & 2.00 & & \\
\hline job: v. little freedom & & 0.1474 & 6.33 & & \\
\hline job: little freedom & & 0.0724 & 3.68 & & \\
\hline job: v. high skill develop. & & 0.0942 & 3.58 & & \\
\hline job: high skill development & & 0.0638 & 3.28 & & \\
\hline job: v. much supported & & -0.1362 & -8.37 & & \\
\hline job: supported & & -0.1184 & -7.09 & & \\
\hline job: high recognition & & 0.0645 & 2.30 & & \\
\hline job: recognition & & 0.0296 & 1.57 & & \\
\hline job: v. adequate pay & & 0.0402 & 1.53 & & \\
\hline job: adequate pay & & -0.0174 & -1.04 & & \\
\hline job: v. poor promotion & & -0.1093 & -6.96 & & \\
\hline job: poor promotion & & -0.0836 & -5.42 & & \\
\hline job: v. poor job security & & 0.0701 & 2.37 & & \\
\hline job: poor job security & & 0.0105 & 0.52 & & \\
\hline expect pension claim: old age & & -0.0412 & -3.29 & & \\
\hline expect pension claim: early ret. & & -0.1393 & -4.31 & & \\
\hline expect pension claim: other & & 0.0584 & 1.92 & & \\
\hline expect pension claim: missing & & 0.2263 & 2.90 & & \\
\hline Number of observations & 4077 & 3880 & & 4061 & \\
\hline log-likelihood & -1980.56 & -1575.22 & & -1844.30 & \\
\hline Pseudo- $R^{2}$ & 0.1626 & 0.2869 & & 0.2169 & \\
\hline
\end{tabular}

Note: This Table displays marginal effects of a probit model explaining self-employment (total selfemployment from main and secondary job). The sample is all male household heads, aged 50-75. Reference groups: education levels 0 and 1 (none, pre-primary, or primary); married couples; reference country: Germany; reference industry: education and health and social work; reference occupation: professionals. job: job characteristics, each with 4 possible answers, coded into dummy variables per characteristic, displaying 'v.': 'strongly agree', or else 'agree'; reference groups: 'disagree' and 'strongly disagree'. All standard errors are based on heteroskedasticity-consistent estimates, all estimates are obtained from multiple imputation routines. Log-likelihood and Pseudo- $\mathrm{R}^{2}$ : refer to values using the first implicate only. 
Table 10: Hours Worked Per Week

\begin{tabular}{|c|c|c|c|c|c|c|c|c|}
\hline \multirow[b]{2}{*}{ variable } & \multicolumn{2}{|c|}{ baseline } & \multicolumn{2}{|c|}{ + occupation } & \multicolumn{2}{|c|}{$\begin{array}{l}+ \text { country-specific } \\
\text { self-employment }\end{array}$} & \multicolumn{2}{|c|}{$\begin{array}{c}\text { base }+ \text { income \& } \\
\text { wealth, }- \text { marit.st. }\end{array}$} \\
\hline & coeff. & $t$-value & coeff. & $t$-value & coeff. & $t$-value & coeff. & $t$-value \\
\hline self-employed & 10.8269 & 16.19 & 9.9649 & 14.70 & 10.4616 & 6.79 & 10.8689 & 16.01 \\
\hline age & 1.6567 & 1.30 & 1.4414 & 1.15 & 1.3374 & 1.07 & 2.0485 & 1.64 \\
\hline age $^{2} / 100$ & -1.5934 & -1.42 & -1.4152 & -1.28 & -1.3193 & -1.19 & -1.9301 & -1.75 \\
\hline edu.: (lower) secondary & 1.3688 & 1.53 & 1.4016 & 1.55 & 1.3722 & 1.54 & 1.3533 & 1.51 \\
\hline edu.: (upper) secondary & 1.3210 & 1.57 & 0.9730 & 1.12 & 1.1094 & 1.31 & 1.2791 & 1.52 \\
\hline edu.: post-sec., non-tertiary & 0.6119 & 0.41 & 0.0052 & 0.00 & 0.1411 & 0.09 & 0.6174 & 0.42 \\
\hline edu.: 1st tertiary & 2.0641 & 2.29 & 1.1673 & 1.19 & 1.2868 & 1.33 & 2.0857 & 2.31 \\
\hline edu.: 2nd tertiary & 5.3133 & 2.25 & 4.3426 & 1.85 & 3.6874 & 1.52 & 5.1772 & 2.20 \\
\hline edu.: other & -0.6194 & -0.24 & -1.3915 & -0.54 & -1.6305 & -0.65 & -0.7154 & -0.27 \\
\hline foreign-born & -2.7248 & -2.73 & -2.1717 & -2.18 & -2.0209 & -2.07 & -2.7328 & -2.73 \\
\hline household size & 0.0219 & 0.09 & 0.0601 & 0.24 & 0.0391 & 0.16 & 0.2003 & 0.86 \\
\hline marital st.: nvr. married & -1.0947 & -1.07 & -0.9262 & -0.91 & -0.9522 & -0.92 & & \\
\hline marital st.: widowed & -1.0458 & -0.58 & -0.5257 & -0.30 & -0.8804 & -0.50 & & \\
\hline marital st.: div./sep. & -1.3257 & -1.47 & -1.1008 & -1.22 & -1.2995 & -1.45 & & \\
\hline private net worth (m EUR) & & & & & & & -0.3068 & -1.10 \\
\hline other hh income (100k EUR) & & & & & & & 0.5785 & 6.36 \\
\hline long-term sickness & -1.5600 & -2.80 & -1.5185 & -2.75 & -1.4701 & -2.67 & -1.6407 & -2.94 \\
\hline number of chronic conditions & 0.0759 & 0.28 & 0.0437 & 0.16 & 0.0204 & 0.08 & 0.0706 & 0.26 \\
\hline number of symptoms & 0.3678 & 1.35 & 0.4704 & 1.74 & 0.4597 & 1.69 & 0.3773 & 1.39 \\
\hline body mass index & 0.2047 & 3.06 & 0.1847 & 2.75 & 0.1891 & 2.78 & 0.2031 & 3.05 \\
\hline Austria & -0.1247 & -0.11 & -0.0238 & -0.02 & 0.8686 & 0.71 & -0.1275 & -0.11 \\
\hline Belgium & -3.0610 & -3.53 & -3.2991 & -3.88 & -3.8846 & -4.57 & -3.0216 & -3.48 \\
\hline Switzerland & 0.9659 & 0.62 & 0.4685 & 0.30 & 1.6146 & 0.87 & 1.0393 & 0.66 \\
\hline Denmark & -3.7007 & -4.31 & -3.5673 & -4.21 & -3.1372 & -3.77 & -3.6507 & -4.23 \\
\hline Spain & -6.3949 & -5.25 & -6.2855 & -5.20 & -3.7901 & -3.10 & -6.5270 & -5.44 \\
\hline France & -3.0652 & -3.58 & -3.2763 & -3.90 & -3.6928 & -4.46 & -3.1548 & -3.70 \\
\hline Greece & -8.1924 & -7.20 & -9.1263 & -7.84 & -11.6936 & -8.12 & -8.2134 & -7.24 \\
\hline Italy & -7.7981 & -6.41 & -7.7273 & -6.42 & -5.7863 & -4.51 & -7.8014 & -6.42 \\
\hline Netherlands & -4.8796 & -6.06 & -4.8832 & -6.13 & -5.1244 & -6.72 & -4.7453 & -5.92 \\
\hline Sweden & -2.0562 & -2.56 & -1.7557 & -2.23 & -0.7152 & -0.93 & -1.9383 & -2.40 \\
\hline self-empl. in Austria & & & & & -4.0175 & -1.32 & & \\
\hline self-empl. in Belgium & & & & & 3.1867 & 1.30 & & \\
\hline self-empl. in Switzerland & & & & & -3.4427 & -1.07 & & \\
\hline self-empl. in Denmark & & & & & -1.9463 & -0.73 & & \\
\hline self-empl. in Spain & & & & & -7.9700 & -2.84 & & \\
\hline self-empl. in France & & & & & 3.2529 & 1.30 & & \\
\hline self-empl. in Greece & & & & & 5.1989 & 2.14 & & \\
\hline self-empl. in Italy & & & & & -4.2201 & -1.62 & & \\
\hline self-empl. in Netherlands & & & & & 0.8116 & 0.32 & & \\
\hline self-empl. in Sweden & & & & & -5.2290 & -2.22 & & \\
\hline ind.: missing & 4.1853 & 3.81 & 1.0047 & 0.84 & 2.3811 & 1.92 & 4.4403 & 4.04 \\
\hline ind.: other & 0.4036 & 0.14 & 0.5856 & 0.19 & 2.3722 & 0.79 & 0.6618 & 0.22 \\
\hline ind.: agriculture \& mining & 8.4835 & 4.71 & 5.2104 & 2.83 & 5.9571 & 3.21 & 8.7952 & 4.83 \\
\hline ind.: manuf., low tech & 3.8797 & 4.21 & 2.9578 & 3.05 & 2.8715 & 2.97 & 4.0782 & 4.44 \\
\hline ind.: manuf., high tech & 2.8848 & 2.94 & 2.0870 & 2.06 & 2.1408 & 2.15 & 3.1623 & 3.24 \\
\hline ind.: supplies \& construction & 4.2198 & 4.37 & 3.3195 & 3.25 & 3.3348 & 3.28 & 4.4125 & 4.58 \\
\hline ind.: wholesale, retail & 4.0870 & 3.66 & 2.1409 & 1.87 & 1.9575 & 1.72 & 4.3188 & 3.89 \\
\hline ind.: transp., comm., finance & 2.7681 & 2.83 & 2.4283 & 2.39 & 2.6796 & 2.64 & 2.9854 & 3.05 \\
\hline ind.: other sophisticated & 2.9685 & 3.53 & 2.3232 & 2.70 & 2.2972 & 2.66 & 3.1694 & 3.78 \\
\hline ind.: other services & 3.4269 & 2.39 & 3.0613 & 2.16 & 3.0895 & 2.19 & 3.5338 & 2.47 \\
\hline occ.: missing & & & 8.6393 & 4.09 & 7.0510 & 3.31 & & \\
\hline occ.: other, inc. armed forces & & & 1.5626 & 0.92 & 1.2542 & 0.72 & & \\
\hline
\end{tabular}


Table 10: Hours Worked Per Week (continued)

\begin{tabular}{|c|c|c|c|c|c|c|c|c|}
\hline \multirow[b]{2}{*}{ variable } & \multicolumn{2}{|c|}{ baseline } & \multicolumn{2}{|c|}{ + occupation } & \multicolumn{2}{|c|}{$\begin{array}{l}\text { +country-specific } \\
\text { self-employment }\end{array}$} & \multicolumn{2}{|c|}{$\begin{array}{l}\text { base +income \& } \\
\text { wealth, -marit.st. }\end{array}$} \\
\hline & coeff. & $t$-value & coeff. & $t$-value & coeff. & $t$-value & coeff. & $t$-value \\
\hline occ.: admin./managerial & & & 5.2619 & 6.27 & 5.0195 & 5.97 & & \\
\hline occ.: technicians & & & 0.6097 & 0.74 & 0.4521 & 0.55 & & \\
\hline occ.: clerks & & & -1.3124 & -1.35 & -1.4923 & -1.54 & & \\
\hline occ.: service/sales workers & & & 0.0672 & 0.05 & -0.0119 & -0.01 & & \\
\hline occ.: skilled farm worker & & & 5.8234 & 3.19 & 4.9171 & 2.70 & & \\
\hline occ.: craftsmen & & & 0.4790 & 0.52 & 0.2296 & 0.25 & & \\
\hline occ.: operators & & & 0.3944 & 0.37 & 0.1031 & 0.10 & & \\
\hline occ.: elementary occupations & & & -2.6365 & -2.12 & -2.7662 & -2.23 & & \\
\hline constant & -8.2165 & -0.23 & -1.0705 & -0.03 & 1.5617 & 0.04 & -20.3741 & -0.57 \\
\hline Number of observations & 3997 & & 3997 & & 3997 & & 3997 & \\
\hline Root MSE & 14.446 & & 14.272 & & 14.184 & & 14.426 & \\
\hline $\mathrm{R}^{2}$ & 0.1345 & & 0.1573 & & 0.1699 & & 0.1367 & \\
\hline
\end{tabular}

Note: This Table displays coefficients of a linear regression explaining hours worked per week. Self-employment refers to both main and secondary job. Further notes: see Table 9. 
Table 11: Hours Worked, Self-Selected Self-employment

\begin{tabular}{|c|c|c|c|c|c|c|}
\hline \multirow[b]{3}{*}{ variable } & \multirow{2}{*}{\multicolumn{2}{|c|}{$\begin{array}{l}\text { Endogenous dummy } \\
\text { variable model }\end{array}$}} & \multicolumn{4}{|c|}{ Endog. switching regression model } \\
\hline & & & \multicolumn{2}{|c|}{ wage-employed } & \multicolumn{2}{|c|}{ self-employed } \\
\hline & coeff. & $t$-value & coeff. & $t$-value & coeff. & $t-$ value \\
\hline self-employed & 8.7821 & 8.52 & & & & \\
\hline age & 1.6135 & 1.30 & -0.4748 & -0.25 & -2.0683 & -0.96 \\
\hline $\mathrm{age}^{2} / 100$ & -1.5540 & -1.42 & 0.3571 & 0.21 & 1.7970 & 0.97 \\
\hline edu.: (lower) secondary & 1.4075 & 1.57 & -0.2711 & -0.31 & 6.4669 & 3.00 \\
\hline edu.: (upper) secondary & 0.9016 & 1.05 & 1.0398 & 1.25 & 1.3282 & 0.63 \\
\hline edu.: post-sec., non-tertiary & -0.0140 & -0.01 & -0.3303 & -0.22 & 0.3689 & 0.10 \\
\hline edu.: 1st tertiary & 1.0965 & 1.13 & 2.1972 & 2.29 & -1.5765 & -0.68 \\
\hline edu.: 2nd tertiary & 4.3309 & 1.85 & 3.2074 & 1.16 & 8.8648 & 1.72 \\
\hline edu.: other & -1.4587 & -0.57 & 0.2270 & 0.11 & -5.0633 & -0.84 \\
\hline foreign-born & -2.2388 & -2.26 & -1.0207 & -1.07 & -8.2277 & -2.58 \\
\hline household size & 0.2025 & 0.88 & -0.2639 & -1.19 & 1.3833 & 2.45 \\
\hline long-term sickness & -1.5518 & -2.82 & -0.8615 & -1.61 & -2.5499 & -1.72 \\
\hline number of chronic conditions & 0.0276 & 0.10 & -0.0599 & -0.22 & -0.3845 & -0.55 \\
\hline number of symptoms & 0.4720 & 1.77 & 0.5436 & 1.97 & -0.1235 & -0.18 \\
\hline body mass index & 0.1842 & 2.76 & 0.1978 & 2.93 & 0.1515 & 0.79 \\
\hline other hh income (100k EUR) & 0.4938 & 4.74 & 0.4074 & 4.66 & 0.8874 & 5.97 \\
\hline constant & -6.7980 & -0.19 & 48.6759 & 0.91 & 84.4313 & 1.35 \\
\hline industry dummies & yes & & yes & & yes & \\
\hline country dummies & yes & & yes & & yes & \\
\hline occupation dummies & yes & & yes & & yes & \\
\hline$\sigma$ & 14.1786 & 53.85 & & & & \\
\hline$\sigma_{\text {wage employed }}$ & & & & & 12.2998 & 41.23 \\
\hline$\sigma_{\text {self employed }}$ & & & & & 21.3586 & 16.27 \\
\hline$\rho$ & 0.0444 & 1.46 & & & & \\
\hline$\rho_{\text {wage employed }}$ & & & & & -0.0417 & -1.15 \\
\hline$\rho_{\text {self employed }}$ & & & & & 0.7179 & 10.78 \\
\hline Sample proportion (\%) & & & & 73.7 & & 26.3 \\
\hline Overall average hours & & & & 40.3 & & 30.3 \\
\hline Self-selected average hours & & & & 40.4 & & 50.8 \\
\hline Counterfact. average hours & & & & 39.8 & & 23.0 \\
\hline Number of observations & 3997 & & & & 3997 & \\
\hline Log-likelihood & -18067.48 & & & & -17868.56 & \\
\hline Wald-test independ. (p-value) & 0.4335 & & & & 0.0000 & \\
\hline
\end{tabular}

Note: This Table displays coefficients of linear regressions explaining hours worked per week, correcting for selectivity. Columns 1-2 refer to an instrumental variable model with endogenous dummy, columns 3-6 refer to a switching regression model. The selectivity equation in both models is specified as in column 3 of Table 9; actual FIML estimates differ very slightly. Exclusion restrictions are marital status indicators and wealth. All equations contain country, industry and occupation dummies. Further notes: see Table 9. 


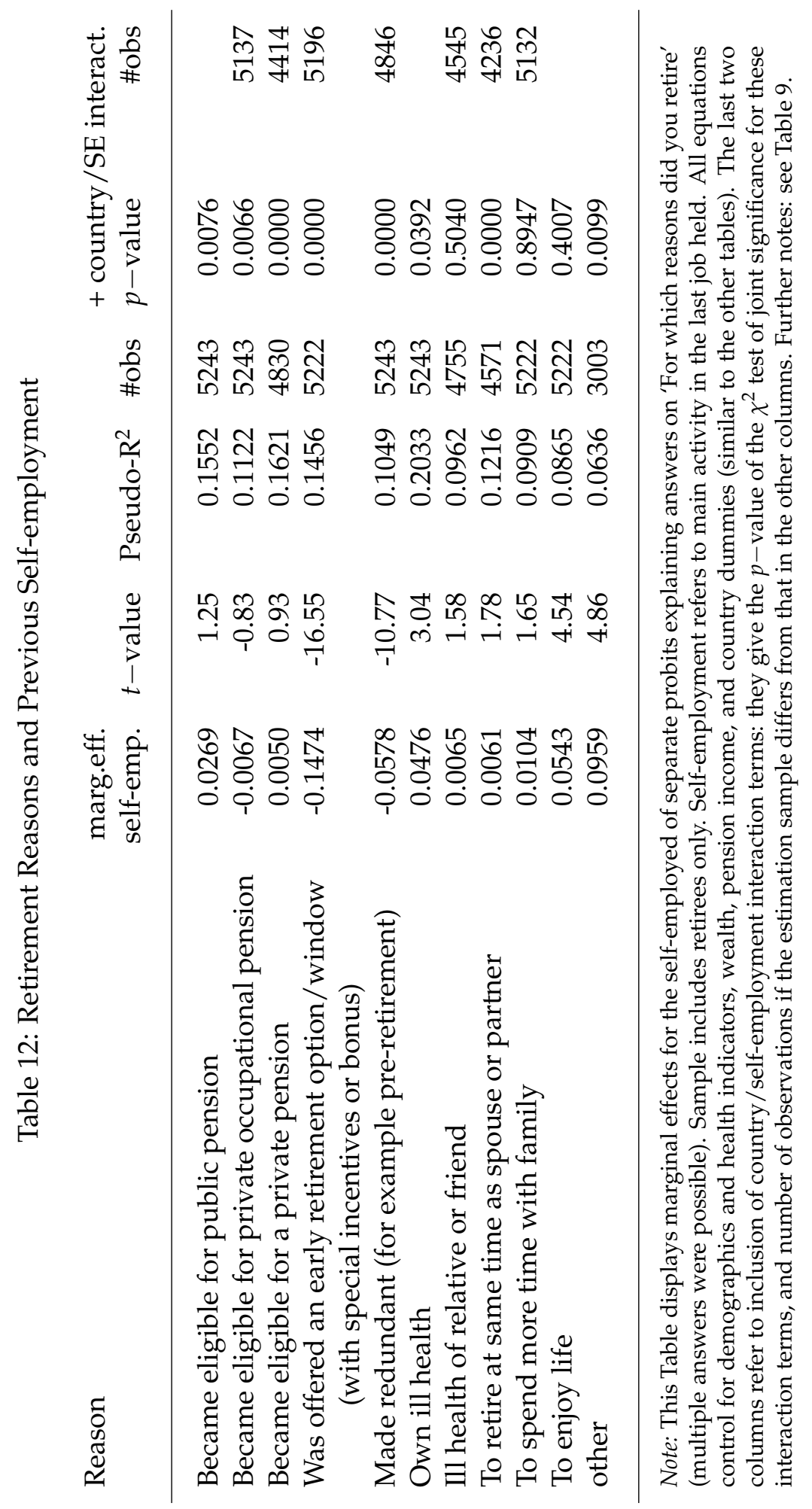


Table 13: Wish to Retire Early

\begin{tabular}{|c|c|c|c|c|c|c|c|c|}
\hline \multirow[b]{2}{*}{ variable } & \multicolumn{2}{|c|}{ baseline } & \multicolumn{2}{|c|}{$\begin{array}{l}\text { + occupation } \\
\text { \& industry }\end{array}$} & \multicolumn{2}{|c|}{$\begin{array}{c}+ \text { job } \\
\text { characteristics }\end{array}$} & \multicolumn{2}{|c|}{$\begin{array}{l}\text { + pension } \\
\text { expectations }\end{array}$} \\
\hline & marg.eff. & $t$-value & marg.eff. & $t$-value & marg.eff. & $t$-value & marg.eff. & $t$-value \\
\hline self-employed & -0.0979 & -5.15 & -0.0938 & -4.50 & -0.0668 & -2.79 & -0.0571 & -2.35 \\
\hline age & -0.0117 & -5.36 & -0.0113 & -5.17 & -0.0086 & -3.64 & -0.0082 & -3.45 \\
\hline edu.: (lower) secondary & -0.0435 & -1.49 & -0.0380 & -1.28 & -0.0367 & -1.16 & -0.0375 & -1.18 \\
\hline edu.: (upper) secondary & -0.0733 & -2.79 & -0.0528 & -1.93 & -0.0350 & -1.18 & -0.0318 & -1.07 \\
\hline edu.: post-sec., non-tertiary & -0.1362 & -2.89 & -0.1013 & -2.03 & -0.0434 & -0.80 & -0.0408 & -0.75 \\
\hline edu.: 1st tertiary & -0.2194 & -8.68 & -0.1624 & -5.37 & -0.1295 & -3.90 & -0.1290 & -3.88 \\
\hline edu.: 2nd tertiary & -0.2365 & -4.06 & -0.1766 & -2.62 & -0.1541 & -2.07 & -0.1641 & -2.20 \\
\hline edu.: other & -0.1457 & -1.73 & -0.1073 & -1.22 & -0.0318 & -0.31 & 0.0161 & 0.15 \\
\hline foreign-born & 0.0177 & 0.53 & 0.0021 & 0.06 & -0.0178 & -0.50 & -0.0096 & -0.27 \\
\hline household size & -0.0164 & -1.89 & -0.0153 & -1.75 & -0.0158 & -1.71 & -0.0142 & -1.52 \\
\hline marital st.: nvr. married & -0.0846 & -2.40 & -0.0925 & -2.61 & -0.1028 & -2.76 & -0.1033 & -2.75 \\
\hline marital st.: widowed & -0.1533 & -2.65 & -0.1579 & -2.71 & -0.1579 & -2.53 & -0.1553 & -2.47 \\
\hline marital st.: div./sep. & -0.1121 & -3.62 & -0.1092 & -3.49 & -0.1209 & -3.69 & -0.1168 & -3.53 \\
\hline long-term sickness & 0.0029 & 0.15 & 0.0018 & 0.09 & -0.0082 & -0.38 & -0.0023 & -0.10 \\
\hline number of chronic conditions & 0.0297 & 3.04 & 0.0303 & 3.07 & 0.0296 & 2.85 & 0.0290 & 2.78 \\
\hline number of symptoms & 0.0427 & 4.59 & 0.0403 & 4.31 & 0.0199 & 1.98 & 0.0206 & 2.05 \\
\hline body mass index & 0.0062 & 2.69 & 0.0063 & 2.72 & 0.0074 & 2.97 & 0.0072 & 2.89 \\
\hline private net worth (m EUR) & -0.0071 & -0.86 & -0.0053 & -0.64 & -0.0029 & -0.35 & -0.0017 & -0.20 \\
\hline other hh income (100k EUR) & -0.0167 & -0.99 & -0.0156 & -0.96 & -0.0107 & -0.71 & -0.0098 & -0.70 \\
\hline Austria & 0.0917 & 2.02 & 0.0931 & 2.03 & 0.1088 & 2.28 & 0.1117 & 2.33 \\
\hline Belgium & -0.1114 & -3.32 & -0.0977 & -2.84 & -0.0946 & -2.56 & -0.1055 & -2.82 \\
\hline Switzerland & -0.1236 & -2.86 & -0.0989 & -2.20 & -0.0391 & -0.80 & -0.0693 & -1.39 \\
\hline Denmark & -0.0519 & -1.35 & -0.0419 & -1.08 & 0.0071 & 0.17 & -0.0843 & -1.74 \\
\hline Spain & 0.1839 & 4.45 & 0.1944 & 4.68 & 0.2161 & 4.94 & 0.2246 & 5.12 \\
\hline France & 0.1278 & 3.50 & 0.1358 & 3.66 & 0.1737 & 4.40 & 0.1692 & 4.20 \\
\hline Greece & 0.0889 & 2.53 & 0.1022 & 2.74 & 0.0578 & 1.43 & 0.0629 & 1.51 \\
\hline Italy & 0.0622 & 1.48 & 0.0746 & 1.75 & 0.0497 & 1.10 & 0.0526 & 1.15 \\
\hline Netherlands & -0.0983 & -2.91 & -0.0808 & -2.28 & -0.0552 & -1.43 & -0.1100 & -2.53 \\
\hline Sweden & -0.0496 & -1.48 & -0.0218 & -0.62 & 0.0331 & 0.89 & 0.0525 & 1.37 \\
\hline ind.: missing & & & -0.0206 & -0.50 & -0.0244 & -0.55 & -0.0216 & -0.49 \\
\hline ind.: other & & & -0.0561 & -0.68 & -0.0267 & -0.31 & -0.0208 & -0.24 \\
\hline ind.: agriculture \& mining & & & -0.0596 & -0.90 & -0.0315 & -0.44 & -0.0183 & -0.25 \\
\hline ind.: manuf., low tech & & & 0.0048 & 0.13 & 0.0235 & 0.61 & 0.0254 & 0.65 \\
\hline ind.: manuf., high tech & & & 0.0687 & 1.52 & 0.0694 & 1.47 & 0.0779 & 1.64 \\
\hline ind.: supplies \& construction & & & -0.0553 & -1.47 & -0.0646 & -1.63 & -0.0599 & -1.50 \\
\hline ind.: wholesale, retail & & & 0.0959 & 2.40 & 0.0872 & 2.05 & 0.0853 & 2.00 \\
\hline ind.: transp., comm., finance & & & -0.0473 & -1.27 & -0.0430 & -1.08 & -0.0396 & -0.99 \\
\hline ind.: other sophisticated & & & -0.0456 & -1.42 & -0.0421 & -1.24 & -0.0398 & -1.17 \\
\hline ind.: other services & & & -0.0118 & -0.26 & 0.0098 & 0.20 & 0.0085 & 0.18 \\
\hline occ.: missing & & & 0.0594 & 0.98 & 0.0458 & 0.70 & 0.0520 & 0.79 \\
\hline occ.: other, inc. armed forces & & & -0.0001 & -0.00 & 0.0027 & 0.04 & 0.0001 & 0.00 \\
\hline occ.: admin./managerial & & & 0.0056 & 0.18 & 0.0152 & 0.46 & 0.0141 & 0.43 \\
\hline occ.: technicians & & & 0.0499 & 1.62 & 0.0462 & 1.43 & 0.0436 & 1.34 \\
\hline occ.: clerks & & & 0.1314 & 3.12 & 0.0956 & 2.13 & 0.0893 & 1.98 \\
\hline occ.: service/sales workers & & & -0.0164 & -0.37 & -0.0708 & -1.52 & -0.0713 & -1.52 \\
\hline occ.: skilled farm worker & & & 0.0992 & 1.77 & 0.0196 & 0.31 & 0.0221 & 0.35 \\
\hline occ.: craftsmen & & & 0.0854 & 2.41 & 0.0306 & 0.80 & 0.0276 & 0.72 \\
\hline occ.: operators & & & 0.1209 & 3.07 & 0.0620 & 1.43 & 0.0614 & 1.41 \\
\hline occ.: elementary occupations & & & 0.1708 & 4.07 & 0.1102 & 2.37 & 0.1195 & 2.55 \\
\hline job: v. satisfied & & & & & -0.2492 & -6.55 & -0.2558 & -6.68 \\
\hline job: satisfied & & & & & -0.0901 & -2.38 & -0.0978 & -2.56 \\
\hline
\end{tabular}


Table 13: Wish to Retire Early (continued)

\begin{tabular}{|c|c|c|c|c|c|c|c|}
\hline \multirow[b]{2}{*}{ variable } & \multicolumn{2}{|c|}{ baseline } & $\begin{array}{l}+ \text { occupation } \\
\text { \& industry }\end{array}$ & \multicolumn{2}{|c|}{$\begin{array}{c}+ \text { job } \\
\text { characteristics }\end{array}$} & \multicolumn{2}{|c|}{$\begin{array}{l}+ \text { pension } \\
\text { expectations }\end{array}$} \\
\hline & marg.eff. & $t$-value & marg.eff. $\quad t$-value & marg.eff. & $t$-value & marg.eff. & $t$-value \\
\hline job: v. phys. demanding & & & & 0.1012 & 3.91 & 0.1040 & 4.00 \\
\hline job: phys. demanding & & & & 0.0495 & 2.23 & 0.0499 & 2.24 \\
\hline job: v. heavy workload & & & & 0.0855 & 3.40 & 0.0835 & 3.30 \\
\hline job: heavy workload & & & & 0.0202 & 0.99 & 0.0170 & 0.83 \\
\hline job: v. little freedom & & & & -0.0771 & -3.05 & -0.0773 & -3.04 \\
\hline job: little freedom & & & & -0.0440 & -1.94 & -0.0420 & -1.84 \\
\hline job: v. high skill develop. & & & & -0.0182 & -0.64 & -0.0213 & -0.75 \\
\hline job: high skill development & & & & -0.0386 & -1.67 & -0.0429 & -1.84 \\
\hline job: v. much supported & & & & -0.0190 & -0.64 & -0.0228 & -0.76 \\
\hline job: supported & & & & -0.0111 & -0.50 & -0.0125 & -0.56 \\
\hline job: high recognition & & & & -0.0841 & -2.73 & -0.0793 & -2.55 \\
\hline job: recognition & & & & -0.0568 & -2.46 & -0.0534 & -2.30 \\
\hline job: v. adequate pay & & & & -0.0477 & -1.51 & -0.0522 & -1.65 \\
\hline job: adequate pay & & & & -0.0258 & -1.27 & -0.0270 & -1.33 \\
\hline job: v. poor promotion & & & & 0.0525 & 2.09 & 0.0471 & 1.87 \\
\hline job: poor promotion & & & & 0.0376 & 1.82 & 0.0360 & 1.73 \\
\hline job: v. poor job security & & & & -0.0048 & -0.14 & -0.0093 & -0.27 \\
\hline job: poor job security & & & & 0.0074 & 0.30 & 0.0053 & 0.22 \\
\hline total hours worked/week & & & & -0.0016 & -2.46 & -0.0016 & -2.55 \\
\hline expect pension claim: old age & & & & & & 0.0103 & 0.65 \\
\hline expect pension claim: early ret. & & & & & & 0.1307 & 4.11 \\
\hline expect pension claim: other & & & & & & -0.0504 & -1.59 \\
\hline expect pension claim: missing & & & & & & -0.0243 & -0.36 \\
\hline Number of observations & 4034 & & 4034 & 3819 & & 3805 & \\
\hline log-likelihood & -2576.75 & & -2548.63 & -2281.24 & & -2262.64 & \\
\hline Pseudo- $R^{2}$ & 0.0757 & & 0.0858 & 0.1364 & & 0.1403 & \\
\hline
\end{tabular}

Note: This Table displays marginal effects of probits for wishing to retire 'as early as you can from' the present job. Self-employment refers to both main and secondary job. Sample and further notes: see Table 9. 
Table 14: Probability of Retiring Between Wave 1 and 2

\begin{tabular}{|c|c|c|c|c|c|c|c|c|}
\hline \multirow{2}{*}{$\begin{array}{l}\text { variable } \\
\text { self-employed }\end{array}$} & \multicolumn{2}{|c|}{ baseline } & \multicolumn{2}{|c|}{$\begin{array}{c}\text { retired only } \\
\text { if not working } \\
\text { marg.eff.t-value }\end{array}$} & \multicolumn{2}{|c|}{$\begin{array}{c}\text { extended } \\
\text { baseline } \\
\text { marg.eff.t-value }\end{array}$} & \multicolumn{2}{|c|}{$\begin{array}{c}\text { same, wealth } \\
\text { instrumented } \\
\text { marg.eff.t-value }\end{array}$} \\
\hline & -0.0443 & -6.05 & -0.0178 & -4.79 & -0.0188 & -1.05 & 0.0035 & 0.07 \\
\hline age & 0.1626 & 9.79 & 0.0429 & 5.16 & 0.1338 & 9.00 & 0.2035 & 3.05 \\
\hline age $^{2} / 100$ & -0.1232 & -8.92 & -0.0327 & -4.78 & -0.0996 & -8.23 & -0.1507 & -3.03 \\
\hline edu.: (lower) secondary & 0.0102 & 0.75 & -0.0046 & -1.06 & 0.0063 & 0.57 & 0.0178 & 0.80 \\
\hline edu.: (upper) secondary & -0.0064 & -0.58 & -0.0058 & -1.30 & -0.0042 & -0.45 & -0.0015 & -0.09 \\
\hline edu.: post-sec., non-tertiary & -0.0204 & -1.40 & - & - & -0.0184 & -1.66 & -0.0294 & -1.18 \\
\hline edu.: 1st tertiary & -0.0199 & -1.93 & -0.0139 & -3.24 & -0.0152 & -1.66 & 0.0011 & 0.04 \\
\hline edu.: 2nd tertiary & -0.0438 & -6.39 & -0.0123 & -3.94 & -0.0357 & -6.42 & -0.0769 & -1.43 \\
\hline edu.: other & 0.0324 & 0.61 & - & - & 0.0330 & 0.63 & 0.0329 & 0.54 \\
\hline foreign-born & -0.0149 & -1.23 & -0.0072 & -1.62 & -0.0127 & -1.33 & -0.0141 & -0.69 \\
\hline household size & -0.0104 & -2.44 & -0.0042 & -2.07 & -0.0065 & -1.80 & -0.0095 & -1.43 \\
\hline marital st.: nvr. married & -0.0262 & -2.60 & -0.0085 & -2.01 & -0.0206 & -2.49 & -0.0479 & -1.33 \\
\hline marital st.: widowed & -0.0285 & -2.51 & -0.0123 & -3.96 & -0.0216 & -2.17 & -0.0495 & -1.28 \\
\hline marital st.: div./sep. & -0.0289 & -3.31 & -0.0080 & -1.92 & -0.0218 & -2.85 & -0.0476 & -1.41 \\
\hline long-term sickness & 0.0050 & 0.58 & 0.0018 & 0.42 & 0.0083 & 1.09 & 0.0032 & 0.24 \\
\hline number of chronic conditions & -0.0025 & -0.61 & -0.0012 & -0.59 & -0.0039 & -1.11 & -0.0057 & -0.98 \\
\hline number of symptoms & 0.0080 & 2.08 & 0.0020 & 1.05 & 0.0064 & 1.92 & 0.0075 & 1.38 \\
\hline body mass index & 0.0005 & 0.56 & -0.0002 & -0.35 & 0.0006 & 0.68 & 0.0008 & 0.61 \\
\hline private net worth (m EUR) & -0.0011 & -0.30 & -0.0016 & -0.83 & -0.0020 & -0.58 & -0.0977 & -0.87 \\
\hline other hh income (100k EUR) & -0.0179 & -1.55 & -0.0023 & -0.65 & -0.0095 & -0.93 & -0.0094 & -0.61 \\
\hline Austria & 0.0801 & 2.05 & 0.0391 & 1.66 & 0.1134 & 2.28 & 0.1257 & 2.62 \\
\hline Belgium & 0.0003 & 0.02 & 0.0014 & 0.20 & 0.0109 & 0.67 & 0.0386 & 0.98 \\
\hline Switzerland & -0.0215 & -1.76 & -0.0112 & -2.95 & -0.0202 & -1.80 & -0.0106 & -0.30 \\
\hline Denmark & -0.0031 & -0.21 & -0.0137 & -4.09 & -0.0283 & -3.58 & -0.0470 & -1.90 \\
\hline Spain & -0.0209 & -1.64 & 0.0091 & 0.75 & -0.0110 & -0.75 & -0.0242 & -0.87 \\
\hline France & 0.0399 & 1.60 & 0.0060 & 0.62 & 0.0613 & 2.02 & 0.1041 & 2.05 \\
\hline Greece & -0.0406 & -4.61 & -0.0086 & -1.71 & -0.0366 & -4.15 & -0.0705 & -1.65 \\
\hline Italy & 0.0495 & 1.67 & 0.0101 & 0.79 & 0.1523 & 2.73 & 0.1983 & 3.13 \\
\hline Netherlands & -0.0013 & -0.09 & -0.0078 & -1.62 & -0.0055 & -0.40 & -0.0072 & -0.30 \\
\hline Sweden & -0.0456 & -5.94 & -0.0194 & -5.04 & -0.0328 & -4.33 & -0.0620 & -1.78 \\
\hline ind.: missing & & & & & 0.0022 & 0.15 & 0.0105 & 0.39 \\
\hline ind.: agriculture \& mining & & & & & -0.0139 & -0.85 & 0.0383 & 0.40 \\
\hline ind.: manuf., low tech & & & & & 0.0154 & 1.08 & 0.0325 & 1.13 \\
\hline ind.: manuf., high tech & & & & & 0.0002 & 0.02 & 0.0011 & 0.05 \\
\hline ind.: supplies \& construction & & & & & 0.0031 & 0.25 & 0.0151 & 0.59 \\
\hline ind.: wholesale, retail & & & & & -0.0161 & -1.64 & -0.0184 & -0.93 \\
\hline ind.: transp., comm., finance & & & & & 0.0459 & 2.07 & 0.0785 & 1.83 \\
\hline ind.: other sophisticated & & & & & 0.0047 & 0.41 & 0.0202 & 0.71 \\
\hline ind.: other services & & & & & 0.0297 & 1.23 & 0.0241 & 0.82 \\
\hline expect pension claim: old age & & & & & 0.0009 & 0.17 & -0.0040 & -0.37 \\
\hline expect pension claim: early ret. & & & & & 0.0480 & 4.56 & 0.0710 & 2.75 \\
\hline expect pension claim: other & & & & & -0.0049 & -0.50 & -0.0021 & -0.12 \\
\hline expect pension claim: missing & & & & & -0.0011 & -0.05 & 0.0316 & 0.38 \\
\hline self-empl. in Austria & & & & & -0.0309 & -3.35 & -0.0750 & -1.19 \\
\hline self-empl. in Belgium & & & & & -0.0339 & -4.41 & -0.0750 & -1.29 \\
\hline self-empl. in Switzerland & & & & & -0.0229 & -1.49 & -0.0500 & -1.09 \\
\hline self-empl. in Denmark & & & & & 0.0388 & 0.70 & 0.1837 & 1.01 \\
\hline self-empl. in Spain & & & & & -0.0112 & -0.45 & -0.0042 & -0.07 \\
\hline self-empl. in France & & & & & -0.0150 & -0.62 & -0.0416 & -0.82 \\
\hline self-empl. in Greece & & & & & 0.0211 & 0.48 & 0.0043 & 0.07 \\
\hline self-empl. in Italy & & & & & -0.0388 & -6.51 & -0.0905 & -1.19 \\
\hline
\end{tabular}


Table 14: Probability of Retiring Between Wave 1 and 2 (continued)

\begin{tabular}{|c|c|c|c|c|c|c|}
\hline \multirow{3}{*}{$\begin{array}{l}\text { variable } \\
\text { self-empl. in Netherlands } \\
\text { self-empl. in Sweden }\end{array}$} & \multirow[t]{3}{*}{$\begin{array}{l}\text { baseline } \\
\text { marg.eff.t-value }\end{array}$} & \multirow[t]{3}{*}{$\begin{array}{c}\text { retired only } \\
\text { if not working } \\
\text { marg.eff.t-value }\end{array}$} & \multicolumn{2}{|c|}{$\begin{array}{c}\text { extended } \\
\text { baseline } \\
\text { marg.eff.t-value }\end{array}$} & \multicolumn{2}{|c|}{$\begin{array}{c}\text { same, wealth } \\
\text { instrumented } \\
\text { marg.eff.t-value }\end{array}$} \\
\hline & & & -0.0314 & -3.71 & -0.0405 & -0.84 \\
\hline & & & -0.0085 & -0.33 & 0.0591 & 0.50 \\
\hline Number of observations & 2738 & 2621 & 2704 & & 2704 & \\
\hline log-likelihood & -753.85 & -374.56 & -705.87 & & -4723.98 & \\
\hline Pseudo- $\mathrm{R}^{2}$ & 0.2716 & 0.2216 & 0.3124 & & & \\
\hline
\end{tabular}

Note: This Table displays marginal effects of probits for retiring between wave 1 and wave 2 of the survey. Retirement status is self-reported. In columns 3-4, retirees are only those that do not also work for money at the same time; two education groups are uninformative in this regression. Self-employment refers to main job. Further notes: see Table 9. The instrumented model in column 7-8 is only based on the first implicate and not multiply imputed.

\section{B Figures}

continued overleaf 


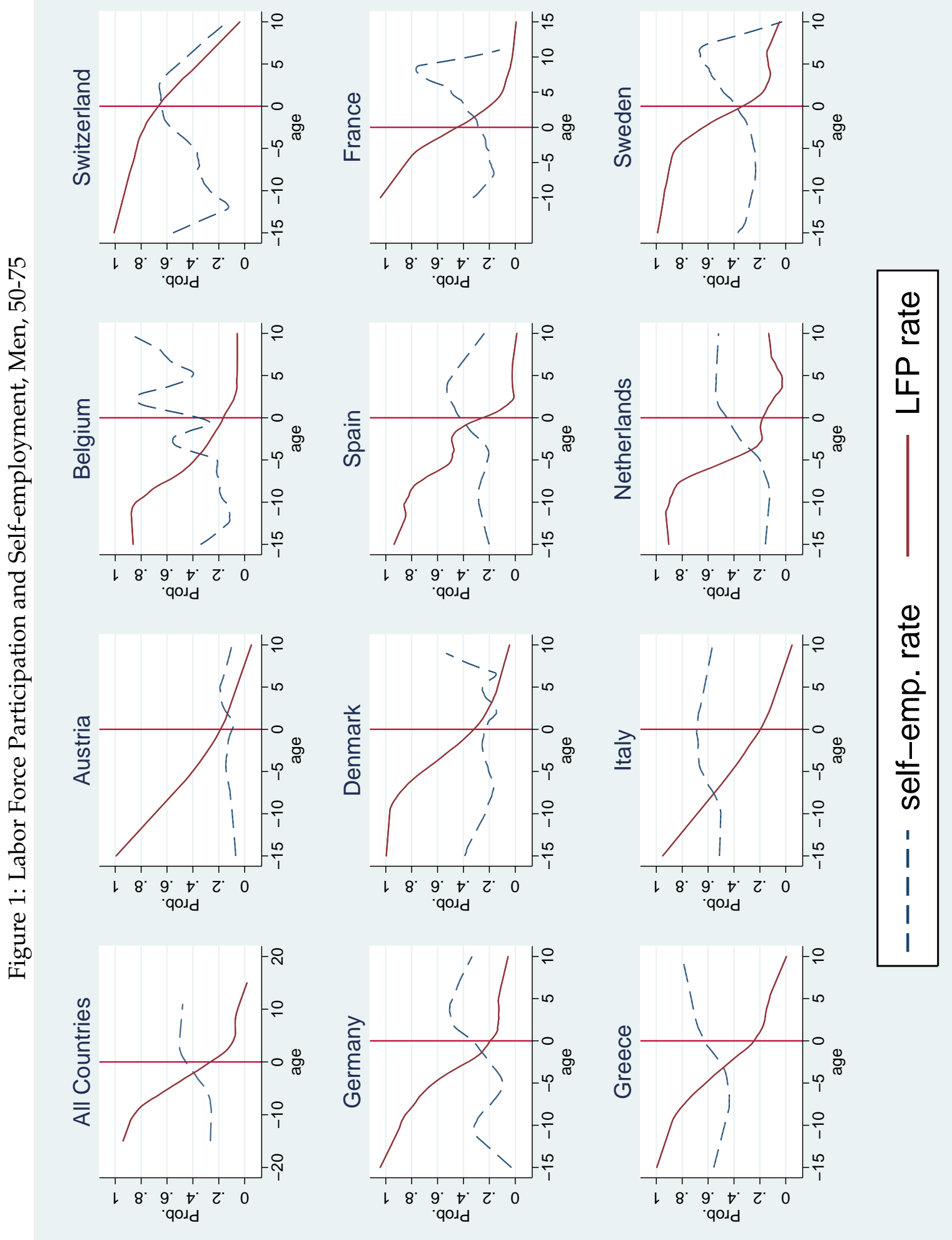




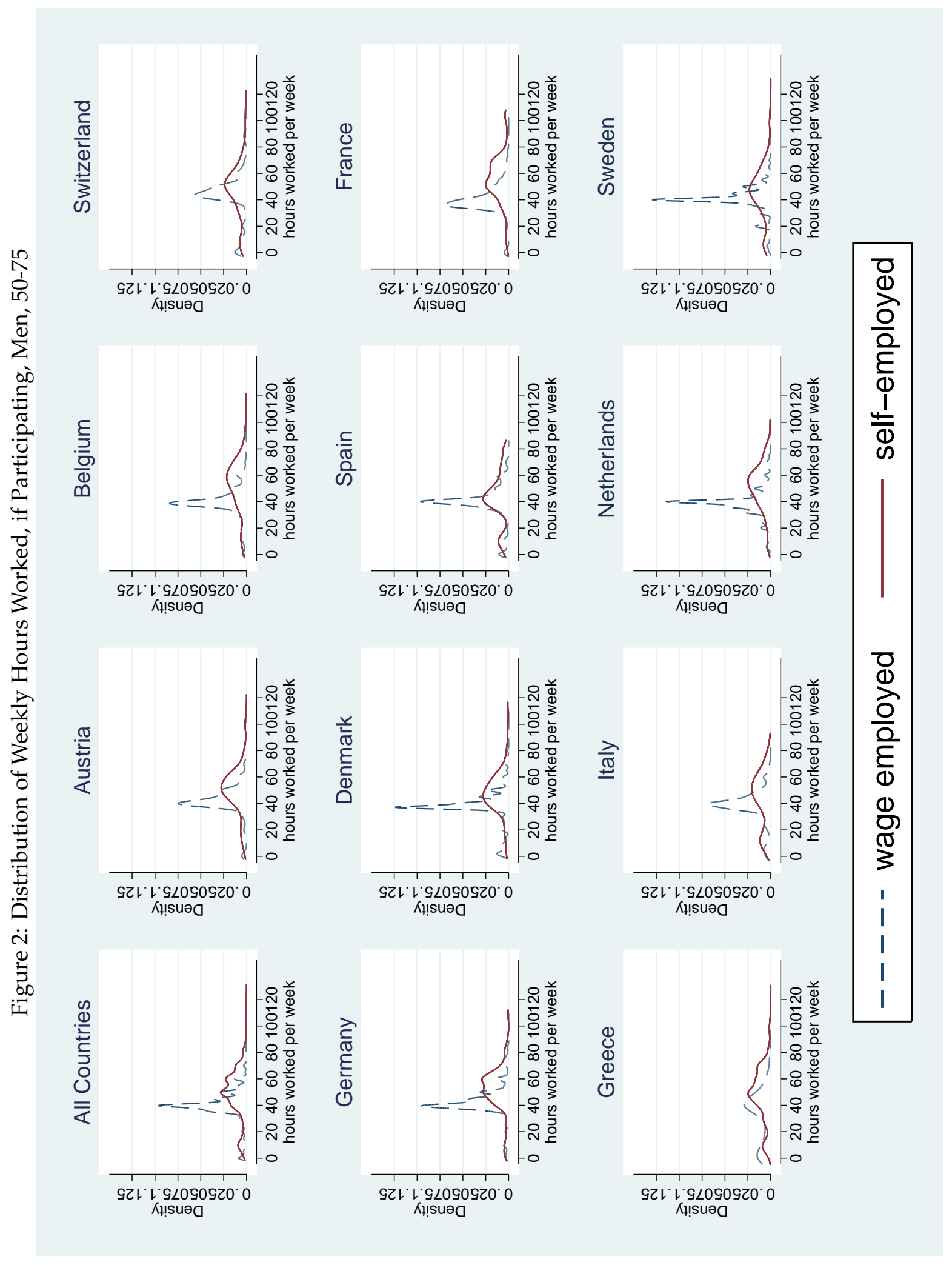




\section{Data Definitions}

\section{C.1 Industry and Occupation Codes}

The SHARE data contain occupation (ISCO) and industry (NACE) codes at low levels of aggregation. We transform ISCO codes to 1-digit occupations and aggregate armed forces, and not codeable or invalid answers into 'other'. We do not classify original responses 'don't know' or 'refusal' into 'missing occupation'. 2-digit industry codes are aggregated to 1-digit codes with the following exceptions: Codes 01 through 14 are coded 'agriculture \& mining'; codes 15 through 28, 37 ('recycling'), and 86 ('production, industry, factory without further specification') are coded 'manuf., low tech.'; codes 29 through 39 (except 37) and 88 ('engineering without further specification') are coded 'manuf., high tech'; codes 40 through 45 are coded 'supplies and construction'; codes 80 through 89 (excluding 86, 87 ('services without further specification'), and 88) are coded 'education, health, and social work'; codes 90 through 99 and 87 are coded 'other services'.

\section{C.2 Software Used}

Analyses rely on Stata (version 11) routines. For Figure 1 Fortran code by Koehler et al. (1997) was used. The switching regressions model has been estimated using software written by Lokshin and Sajaia (2008). Multiple-imputation estimation has been performed with either Stata routines, or those of Robinson and Blanchette (2009), or were hand-coded.

\section{C.3 Data Acknowledgment}

This paper uses data from SHARE release 2.3.0, as of November 13th 2009. SHARE data collection in 2004-2007 was primarily funded by the European Commission through its 5th and 6th framework programmes (project numbers QLK6-CT-2001- 00360; RII-CT- 2006062193; CIT5-CT-2005-028857). Additional funding by the US National Institute on Aging (grant numbers U01 AG09740-13S2; P01 AG005842; P01 AG08291; P30 AG12815; Y1-AG4553-01; OGHA 04-064; R21 AG025169) as well as by various national sources is gratefully acknowledged (see http://www . share-project.org for a full list of funding institutions). 